\title{
New species and new records of cercosporoid hyphomycetes from Cuba and Venezuela (Part 3)
}

\author{
Braun $\mathrm{U}^{1^{*}}$ and Urtiaga $\mathbf{R}^{2}$ \\ ${ }^{I}$ Martin-Luther-Universität, Institut für Biologie, Bereich Geobotanik und Botanischer Garten, Herbarium, Neuwerk \\ 21, 06099 Halle (Saale), Germany \\ ${ }^{2}$ Apartado 546, Barquisimeto, Lara, Venezuela.
}

Braun U, Urtiaga R 2013 - New species and new records of cercosporoid hyphomycetes from Cuba and Venezuela (Part 3). Mycosphere 4(3), 591-614, Doi 10.5943/mycosphere/4/3/12

\begin{abstract}
Examinations of specimens of cercosporoid leaf-spotting hyphomycetes made between 1966 and 1997 in Cuba and Venezuela, now housed at K (previously deposited at IMI as "Cercospora sp."), have been continued, supplemented by several samples collected in Venezuela between 2006 and 2012, which are now deposited at HAL. Some species are new to Cuba and Venezuela, some new host plants are included, and the following new species are introduced: Cercospora syngoniicola, Pseudocercospora apeibae, P. clematidis-haenkeanae, P. erythrinicola, $P$. erythroxylicola, $P$. guanarensis, $P$. helicteris, $P$. simirae, and Zasmidium cassiae-grandis. The new combination Pseudocercospora angraeci and the new name $P$. ranjita var. amphigena are proposed.
\end{abstract}

Key words - Ascomycota - Mycosphaerellaceae - Cercospora - Cercosporella - Passalora Pseudocercospora - Zasmidium - South America - West Indies

\section{Introduction}

Braun \& Urtiaga $(2008,2012,2013)$ and Braun et al. (2010) published results of examinations of collections of cercosporoid, mostly leaf-spotting hyphomycetes from Cuba and Venezuela, which are continued in the present paper. The material concered was collected by R. Urtiaga between 1966 and 1996 and later deposited at IMI as Cercospora sp. (recently completely transferred to K). These specimens have recently been sent on loan to the first author to be determined and for further treatment. Additional Venezuelan collections made between 2006 and 2012 have been directly sent to the first author and are now deposited at HAL.

Results of these examinations supplement hitherto existing contributions to the knowledge of cercosporoid fungi of Cuba (Arnold 1986, Castañeda \& Braun 1989, Braun \& Castañeda 1991, Vilaró Carmino et al. 2006) and Venezuela (Chupp 1934, Dennis 1976, Pons 1984, 1988, 1993, 2004, 2007, Urtiaga 1986, García et al. 1996, Itturiaga \& Minter 2006). Older data are also summarized in Crous \& Braun (2003).

\section{Methods}

Sporulating structures were mounted in distilled water without any staining, and examined using oil immersion (bright field and phase contrast), with standard light microscopy (Olympus BX 
50, Hamburg, Germany). Thirty measurements ( $\times 1000$ magnification) of conidia and other structures were made, with the extremes given in parentheses. All drawings have been prepared by the first author.

\section{Results and discussion}

New records of cercosporoid hyphomycetes from Cuba and Venezuela and descriptions of new species are listed in alphabetical order by genus and species. Discussions and comments are added to each taxon.

Cercospora ageraticola Goh \& W.H. Hsieh (= C. apii complex [s. lat.])

Material examined - VENEZUELA, Lara, Villanueva, on leaves of Chromolaena laevigata (Lam.) R.M. King \& A. Rob. [三Eupatorium laevigatum Lam.] (Asteraceae), Nov. 2008, R. Urtiaga (HAL 2350 F); Carabobo, Chirgua, Hacienda Monte Sacro, on Condylidium iresinoides (Kunth) R.M. King \& H. Rob. [三 Eupatorium iresinoides Kunth] (Asteraceae), May 2001, R. Urtiaga 357 (HAL $2576 \mathrm{~F}$ ).

Notes - The collection on Chromolaena laevigata was originally identified as Calea sp. and recorded by Braun et al. (2010) as Cercospora caleifolia Bat., J. Upadhyay \& Netto. Morphological differences between the collection from Venezuela and the type collection from Brazil were discussed. The identity of the host plant was checked by botanists from the herbarium in Maracay and corrected to Chromolaena laevigata. The present collection belongs to the $C$. apii complex ( $C$. apii s. lat.) in the sense of Crous \& Braun (2003). The name $C$. ageraticola is available for collections on Eupatorium and allied genera (see Guo et al. 2005). The collection on Condylidium iresinoides is characterized by having small, brown stromata, 10-40 $\mu \mathrm{m}$ diam., fasciculate conidiophores, 30-150 $\times 3-6 \mu \mathrm{m}$, up to $8 \mu \mathrm{m}$ wide near the base, pluriseptate, pale to medium brown, paler towards the tip, conidiogenous cells integrated, terminal and often also intercalary, conidiogenous loci 2-3 $\mu \mathrm{m}$ diam., condia aciculate, hyaline, up to $100 \times 3-4 \mu \mathrm{m}$. C. ageraticola is new to Venezuela, and the two hosts are also new for this species.

Cercospora apii Fresen. s. lat. (C. apii complex, sensu Crous \& Braun 2003)

Material examined - CUBA, Bayamo, on living leaves of Cananga odorata (Lam.) Hook. f. \& Thomson (Annonaceae), 12 Oct. 1967, R. Urtiaga 962 (IMI $129576=$ K(M) 173073); Bayamo, on living leaves of Dianthus caryophyllus L. (Caryophyllaceae), 28 Sep. 1967, R. Urtiaga 904 (IMI $129454=\mathrm{K}(\mathrm{M})$ 173053). VENEZUELA, Lara, Duaca zone, on living leaves of Milleria quinqueflora L. (Asteraceae), Nov. 1993, R. Urtiaga (IMI 361861 = K(M) 180152); on living leaves of Philodendron sp. (Araceae), Guanare, Corozal, June 1990, R. Urtiaga (IMI $344203=$ $\mathrm{K}(\mathrm{M})$ 180154).

Notes - Milleria quinqueflora and Philodendron sp. are new host species for C. apii s. lat. Cananga odorata and Dianthus caryophyllus were recorded from Cuba as hosts of Cercospora sp. (Urtiaga 1886, Mercado Sierra et al. 1997, Vilaró Camino et al. 2006). Collections on Dianthus were described as Cercospora dianthi A.S. Mull. \& Chupp. However, this name is invalid and was reduced to synonym with $C$. apii s. lat. by Crous \& Braun (2003).

Cercospora brachiata Ellis \& Everh.

Material examined - CUBA, Bayamo, on living leaves of Amaranthus crassipes Schltdl. (Amaranthaceae), 12 Nov. 1966, R. Urtiaga (IMI 123565 = K(M) 173069).

Notes - Amaranthus crassipes was recorded from Cuba as host of Cercospora sp. in Urtiaga (1986).

\section{Cercospora echinochloae Davis}

Material examined - VENEZUELA, Yaracuy, Chivacoa, on living leaves of Echinochloa colona (L.) Link (Poaceae), 14 Mar. 1969, R. Urtiaga 201 (IMI 139295 = K(M) 180150).

Notes - Known from Venezuela (Dennis 1970, Crous \& Braun 2003). 
Cercospora oxalidis A.S. Mull. \& Chupp ex U. Braun \& Crous

Material examined - VENEZUELA, Lara, Sanare, Sabana Redonda Arriba, on living leaves of Oxalis corniculata L. [三 Xanthoxalis corniculata (L.) Small] (Oxalidaceae), June 2009, R. Urtiaga 281 (HAL 2582 F).

Notes - New to Venezuela on a new host species (hitherto only known from Brazil and USA on Oxalis sp., see Crous \& Braun (2003).

\section{Cercospora rottboeliigena Y.L. Guo \& Y. Jiang}

Material examined - VENEZUELA, Yaracuy, on living leaves of Rottboelia exaltata L. $\mathrm{f}$. (Poaceae), 29 Mar. 1969, R. Urtiaga 272 (IMI 139322 = K(M) 180151).

Notes - New to Venezuela. Recorded in Urtiaga (1986) as Cercospora sp.

Cercospora syngoniicola U. Braun \& Urtiaga, sp. nov. MycoBank, MB 803850.

Fig. 1

Etymology - derived from the host genus, Syngonium.

Cercosporae xanthosomatis similis sed maculis distinctis, ad $18 \mathrm{~mm}$ diam., conidiis brevioribus, ad $120 \mu \mathrm{m}$ longis, hyalinis.

Leaf spots amphigenous, subcircular to angular-irregular, 2-18 $\mathrm{mm}$ diam., brownish, olivaceous-brown, greyish to medium brown, later with paler centre, greyish brown to greyish white, with a narrow darker border or diffuse brownish halo, occasionally somewhat zonate. Caespituli amphigenous, mostly epiphyllous, finely punctiform, dark. Mycelium internal. Stromata lacking or small immersed aggregations of swollen hyphal cells, 10-25 $\mu \mathrm{m}$ diam., olivaceousbrown, cells $2.5-11 \mu \mathrm{m}$ diam. Conidiophores solitary or in small fascicles, 2-15, arising from immersed hyphae or stromata, erumpent, loose to dense, erect, straight, subcylindrical or attenuated towards the tip, geniculate-sinuous, unbranched, 10-90 × 3-9 $\mu \mathrm{m}, 0-5$-septate, pale to medium olivaceous-brown or yellowish brown, thin-walled, smooth; conidiogenous cells integrated, terminal or conidiophores reduced to conidiogenous cells, 10-30 $\mu \mathrm{m}$ long, conidiogenous loci inconspicuous, occasionally subdenticulate, but always unthickened and not darkened. Conidia solitary, acicular to distinctly oblavate, 30-120 × 3-6 $\mu \mathrm{m}, 3-10$-septate, colourless, thin-walled, smooth, apex obtuse to subacute, base truncate to distinctly obconically truncate, hila $2-3.5 \mu \mathrm{m}$ wide, thickened and darkened.

Material examined - VENEZUELA, Lara, Duaca, on living leaves of Syngonium sp. (Araceae), Nov. 1993, R. Urtiaga (IMI $361860=$ K(M) 180153, holotype).

Notes - There are several morphologically similar species on other hosts of the Araceae. Pseudocercospora xanthosomatis Gonz.Frag. \& Cif. is rather similar, but the conidiophores are much longer (up to $300 \mu \mathrm{m}$ ) and the conidia are 50-250 $\mu \mathrm{m}$ long (Chupp 1954).

C. alocasiae Goh \& W.H. Hsieh, C. aracearum Firdousi, A.N. Rai \& K.M. Vyas, C. caladii Cooke, C. colocasigena S. Narayan, Kharwar, R.K. Singh \& Bhartiya, and C. monsterae S. Narayan, Kharwar \& R.K. Singh are characterized by their consistently acicular, narrower conidia and belong to the C. apii complex (Chupp 1954, Firdousi et al. 1991, Hsieh \& Goh 1990, Narayan et al. 1997, 2001), C. pistiae has very long conidiophores, up to $250 \mu \mathrm{m}$ (Nag Raj et al. 1971), $C$. chevalieri Sacc. differs in having very long conidiophores, up to $250 \mu \mathrm{m}$, and broader conidia, 5-7 $\mu \mathrm{m}$ wide (Chupp 1954, Ellis 1976), C. amorphophallicola U. Braun has narrower conidia, 2-3.5 $\mu \mathrm{m}$ (Braun 2001a), and the conidia of $C$. arisematis F.L. Tai turn pale olivaceous with age (Chupp 1954, Guo et al. 2005).

Cercosporella virgaureae (Thüm.) Allesch.

Material examined - VENEZUELA, Lara, Sanare, Sabana Redonda Arriba, on living leaves of Conyza bonariensis (L.) Cronquist (Asteraceae), May 2009, R. Urtiaga 343 (HAL 2575 F). 


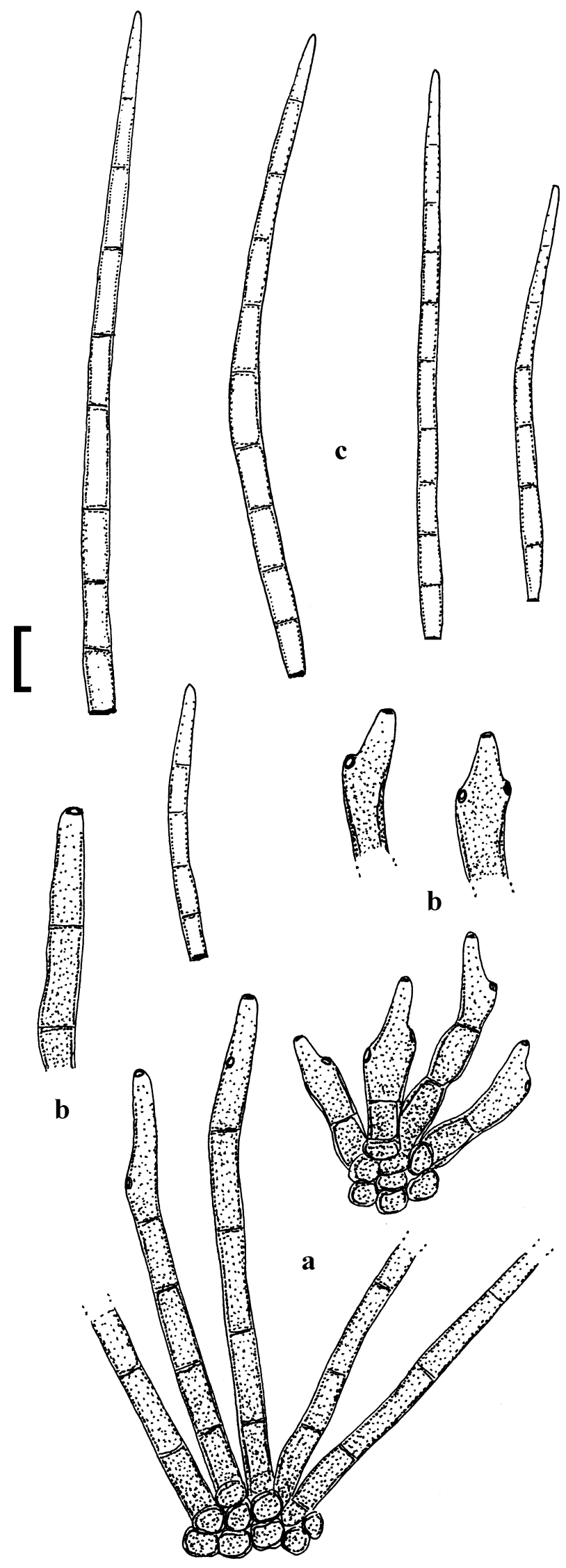

Fig. 1 - Cercospora syngoniicola. Based on type material. a Conidiophore fascicles. b Tips of conidiophores. c Conidia. $-\mathrm{Bar}=10 \mu \mathrm{m}$. 
Notes - Braun \& Urtiaga (2013) published a first record of this species from Venezuela, but on Conyza canadensis.

Passalora calotropidis (Ellis \& Everh.) U. Braun

三Cercospora calotropidis Ellis \& Everh.

Material examined - VENEZUELA, Lara, Quidor, Guadalupe, on living leaves of Calotropis procera (Aiton) Dryand. (Apocynaceae), June 2006, R. Urtiaga 9 (HAL 2159 F)

Notes - Known from Venezuela (Crous \& Braun 2003, Iturriaga \& Minter 2006).

Passalora cajani (Henn.) U. Braun \& Crous

Material examined - VENEZUELA, Lara, Sanare, Sabana Redonda Arriba, on living leaves of Cajanus cajan (L.) Huth (Fabaceae), May 2009, R. Urtiaga 350 (HAL 2583 F).

Notes - Known from Venezuela (Crous \& Braun 2003, Iturriaga \& Minter 2006).

Passalora liabi (Syd. \& P. Syd.) U. Braun \& Crous

$\equiv$ Cercospora liabi Syd. \& P. Syd.

Material examined - VENEZUELA, Lara, Moran, Villanueva, on living leaves of Munnozia hastifolia (Poepp.) H. Rob. \& Brettell [三Liabum hastifolium Poepp.] (Asteraceae), June 2009, R. Urtiaga 283 (HAL 2577 F).

Notes - New to Venezuela and on a new host species (Crous \& Braun 2003, Iturriaga \& Minter 2006). This species was described from Colombia on Munnozia senecionidis Benth. (= Liabum hastatum Britton, nom. inval.).

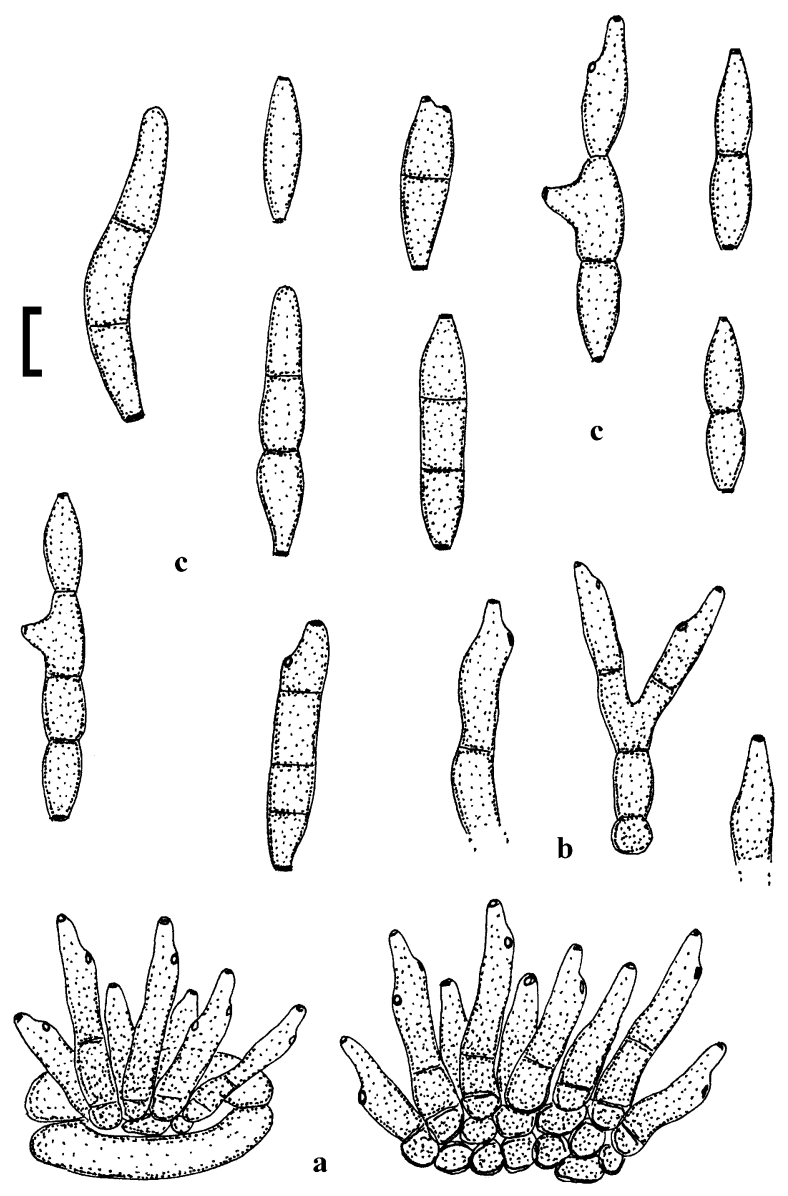

Fig. 2 - Passalora sidigena. Based on type material. a Conidiophore fascicles. b Conidiophores. c Conidia. - Bar $=10 \mu \mathrm{m}$. 
MycoBank, 803851.

Passalorae sidae-mysorensis valde similis sed fasciculis conidiophorum bene evolutis, conidiophoris brevioribus, $10-65 \mu$ m longis.

Leaf spots amphigenous, subcircular to irregular, 1-10 mm diam. or diffuse, on the upper leaf surface mostly rather inconspicuous or formed as diffuse yellowish or pale brownish discolorations, on the lower side mainly caused by brown fungal colonies. Caespituli hypophyllous, punctiform to effuse, brown, loose to rather dense. Mycelium internal. Stromata lacking or small, usually substomatal, 10-25 $\mu \mathrm{m}$, brown. Conidiophores in small to mostly well-developed fascicles, loose to dense, arising from substomatal hyphae or stromata, emerging through stomata, erect, straight to somewhat geniculate-sinuous, unbranched or often branched, sometimes branched near the base, 10-65 × 3-7 $\mu \mathrm{m}, 0-3$-septate, pale to medium olivaceous or olivaceous-brown, thinwalled, smooth; conidiogenous cells integrated, terminal or conidiophores aseptate, i.e. reduced to conidiogenous cells, 10-30 $\mu \mathrm{m}$ long, conidiogenous loci conspicuous, somewhat thickened and darkened, 1-2 $\mu \mathrm{m}$ diam. Conidia in simple or branched chains, ellipsoid-fusiform, cylindrical, occasionally almost obclavate, $12-50 \times 4-8 \mu \mathrm{m}, 0-3$-septate, subhyaline to pale olivaceous or olivaceous-brown, wall thin, smooth or almost so, ends rounded to short obconically truncate, hila 1-1.5 $\mu \mathrm{m}$ wide, slightly thickened and darkened.

Material examined - VENEZUELA, Lara, Sanare, Sabana Redonda Arriba, on living leaves of Sida rhombifolia L. (Malvaceae), June 2009, R. Urtiaga 255 (HAL 2584 F, holotype).

Notes - Pseudocercospora sidae-mysorensis, described from Thailand on Sida mysorensis Wight \& Arn., is morphologically close to $P$. sidigena but differs in having much longer conidiophores, about 80-110 $\mu \mathrm{m}$ long, formed in small fascicles of only 5-12 conidiophores (Meeboon et al. 2007). P. sidigena is a Phaeoramularia-like species of Passalora, i.e. superficial mycelium with solitary conidiophores is not developed, and the conidia are formed in chains. In Passalora sidae-cordifoliae Crous, U. Braun \& Alfenas and P. althaeigena (J.M. Yen \& S.K. Sun) U. Braun \& Crous, two other Passalora species on malvaceous hosts, the conidia are formed singly (Yen \& Sun 1983, Crous et al. 1999). All other Passalora species on hosts belonging to the Malvaceae are Mycovellosiella-like, i.e. they are characterized by forming superficial hyphae with solitary conidiophores: Passalora bastardiae (Petr. \& Cif.) U. Braun \& Crous, P. hughesii (Munt.Cvetk.) U. Braun \& Crous, P. malvacearum (B. Rai \& Kamal) U. Braun \& Crous and $P$. pavoniicola U. Braun \& F.O. Freire (Muntañola 1960, Braun 1998, Rai \& Kamal 1985, Braun \& Freire 2004).

Pseudocercospora angraeci (Feuilleb. \& Roum.) U. Braun \& Urtiaga, comb. nov.

Fig. 3 MycoBank, MB 803852.

Bas.: Cercospora angraeci Feuilleb. \& Roum. [“angreci”], Rev. Mycol. 5: 177, 1883.

Material examined - VENEZUELA, Barquisimeto, on living leaves of Cattleya mossiae Hook. (Orchidaceae), 10 Jan. 1996, R. Urtiaga (IMI 370119 = K(M) 180170).

Notes - Crous \& Braun (2003) examined several syntype collections of $C$. angraeci (Roum., Fungi Sel. Exs. 2522, from B, LEP and PC), but failed to find sufficient fructification for the final conclusion about the generic affinity of this species. Chupp (1954) did also not find any conidiophores and conidia in original collections. Chupp (1954) and Crous \& Braun (2003) listed records on Jumenella fragrans (Thouars) Schltr. (三 Angraecum fragrans Thouars), Cattleya sp., Laelia sp., Oncidium sp. and Odontoglossum crispum Lindl. (= O. alexandrae Bateman) from France, Island of Bourbon, UK, and USA (Florida). The present collections from Venezuela is well-developed and agrees very well with Chupp's (1954) concept of this species, which we follow. However, an epitypification (or possibly neotypification) with material on Jumenella fragrans, at best from the Island of Bourbon, is necessary. Due to unthickened, not darkened conidiogenous loci and conidial hila, this species has to be reallocated to Pseudocercospora. The specimen from Venezuela is characterized as follows: Leaf spots small to large, 1-20 mm diam. or confluent and larger, subcircular to somewhat irregular, dingy grey to blackish, mainly due to abundant colonies; 


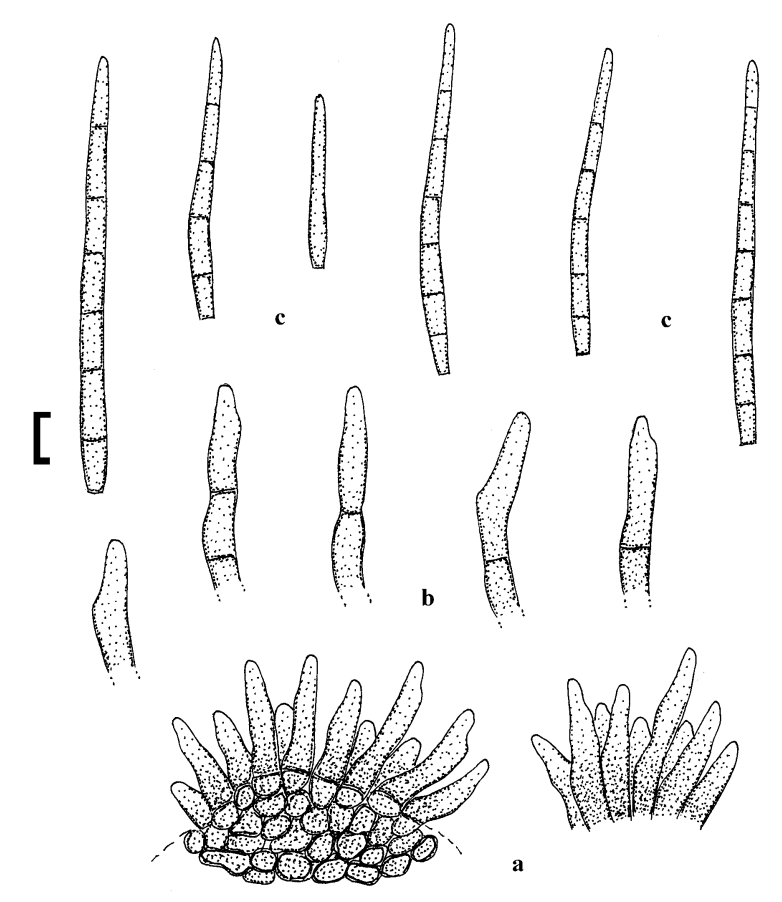

Fig. 3 - Pseudocercospora angraeci. Based on $\mathrm{K}(\mathrm{M})$ 180170. a Conidiophore fascicles. b Conidiophores. c Conidia. - Bar $=10 \mu \mathrm{m}$.

caespituli amphigenous, punctiform, scattered to gregarious, blackish; mycelium internal; stromata immersed, large, 20-90 $\mu \mathrm{m}$ diam., dark olivaceous-brown; conidiophores in dense fascicles, numerous, arising from stromata, erumpent, straight to somewhat sinuous, but not geniculate, unbranched, subcylindrical to somewhat attenuated towards the tip, apex usually obtuse, 0-3septate, pale to medium olivaceous or olivaceous-brown, thin-walled, smooth; conidiogenous cells integrated, terminal, 10-25 $\mu \mathrm{m}$ long, conidiogenous loci inconspicuous; conidia solitary, obclavatecylindrical, with short obconically truncate base, occasionally subacicular, with truncate base, apex obtuse, $20-85 \times 2.5-4.5 \mu \mathrm{m},(0-) 2-8$-septate, pale oliveceous to olivaceous-brown, thin-walled, smooth, hila 1.5-2.5 $\mu \mathrm{m}$ diam., neither thickened nor darkened.

Pyseudocercospora apeibae U. Braun \& Urtiaga, sp. nov. Fig. 4

MycoBank, MB 803853.

Etymology - epithet derived from the host genus, Apeiba.

Pseudocercosporae grewiigenae similis, sed maculis distinctis, conidiophoris longioribus, ad $90 \mu \mathrm{m}$, ad 4-septatis et conidiis angustioribus, $(2-) 3-4.5(-5) \mu \mathrm{m}$.

Leaf spots amphigenous, subcircular to usually angular-irregular, 1-30 $\mathrm{mm}$ diam. or confluent and larger, medium to dark brown, later greyish brown to greyish white with darker border, partly limited by veins and with a diffuse yellowish, ochraceous to yellow-brown halo. Caespituli amphigenous, conspicuous on the upper side, punctiform, scattered, dark brown to blackish, inconspicuous below. Mycelium internal and on the lower side also external. Stromata well-developed, 10-60 $\mu \mathrm{m}$ diam., only epiphyllous, immersed, medium brown or olivaceousbrown, cells $2-8 \mu \mathrm{m}$ diam. Conidiophores in small to moderately large fascicles, divergent to moderately dense, arising from stromata, erumpent, rarely solitary, arising from superficial hyphae (only on the lower side), erect, straight, subcylindrical or somewhat narrowed towards the tip, slightly geniculate-sinuous, unbranched, $10-90 \times 2-7 \mu \mathrm{m}, 0-4$-septate, pale to medium olivaceousbrown, wall thin to somewhat thickened, up to $1 \mu \mathrm{m}$, smooth; conidiogenous cells integrated, terminal or conidiophores occasionally reduced to conidiogenous cells, 10-30 $\mu \mathrm{m}$ long, coni- 


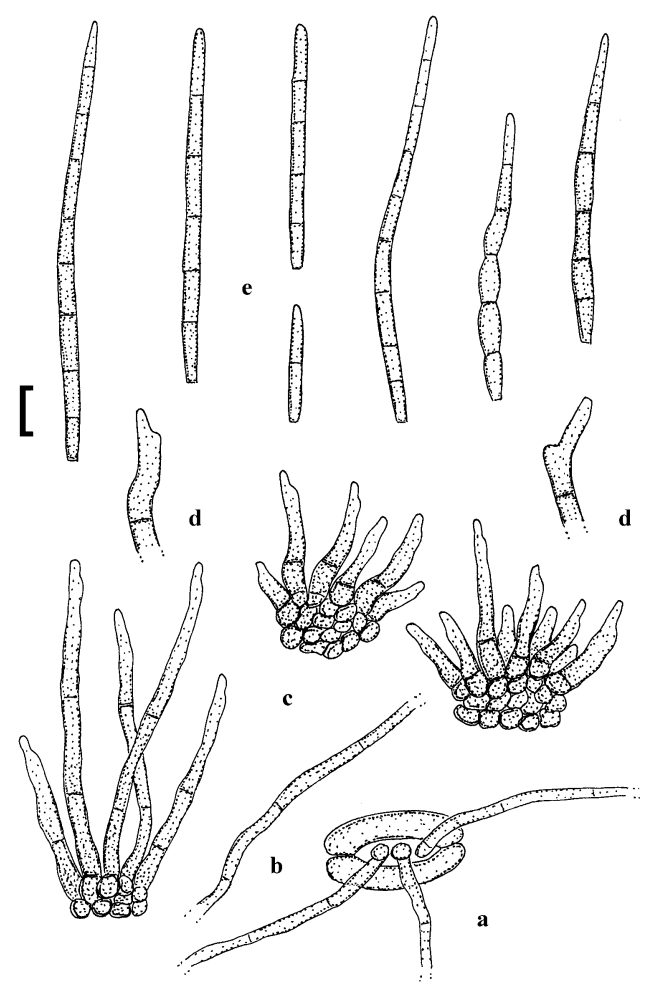

Fig. 4 - Pseudocercospora apeibae. Based on type material. a Superficial hyphae emerging through a stoma. b Superficial hypha. Conidiophore fascicle. c Conidiophore fascicles. d Tips of conidia. e Conidia. - Bar $=10 \mu \mathrm{m}$.

diogenous loci inconspicuous. Conidia solitary, obclavate to obclavate-cylindrical, (10-)20-85($110) \times(2-) 3-4.5(-5 \mu \mathrm{m}),(0-) 1-4$-septate, pale to medium olivaceous or olivaceous-brown, thinwalled, smooth or almost so, apex obtuse to subacute, base obconically truncate, hila 1-2 $\mu \mathrm{m}$ broad, neither thickened nor darkened.

Material examined - VENEZUELA, Barinas, Chorrosco, on leaves of Apeiba tibourbou Aubl. (Malvaceae, Grewioideae [三 Grewiaceae]), June 1991, R. Urtiaga (IMI $353983=$ K(M) 180176, holotype).

Notes - The present collection is listed as Pseudocercospora sp. in Iturriaga \& Minter (2006). There are several species of Pseudocercospora on hosts of allied genera belonging to the Grewioideae (Grewiaceae). P. grewiicola Y.L. Guo (Liu \& Guo 1998) on Grewia in China is very similar, but differs in having different lesions, shorter conidiophores $(10-40 \mu \mathrm{m})$, only 0-2-septate, and broader conidia, 3-6.5 $\mu \mathrm{m}$. The African P. berryae Deighton (Deighton 1979) on the less closely allied hosts Berrya cordifolia (Willd.) Burrnet and Christiana africana DC. is also comparable, but stromata are lacking and the conidiophores are only up to $40 \mu \mathrm{m}$ long and $0-1(-2)$ septate. P. grewiicola (Govindu \& Thirum.) Bagyan., U. Braun \& Jagad. and P. tiliacearum Bhalla, A.K. Sorbhoy, M. Kulshr. \& K.P.S. Kushawa, both on Grewia sp. in India (Bagyanarayana et al. 1995, Bhalla et al. 2001), and P. triumfettae (Syd.) Deighton (Chupp 1954, Deighton 1976) on Triumfetta spp. are easily distinguishable by lacking stromata and conidiophores that are consistently formed singly. In addition, the conidia of $P$. tiliacearum are quite distinct (up to about $150 \mu \mathrm{m}$ long and only 1.5-2.5 $\mu \mathrm{m}$ wide). P. corchorica (Petr. \& Cif.) Deighton (Deighton 1976) and the Indian P. mannanorensis Bagyan., U. Braun \& Jagad. (Bagyanarayana et al. 1995) on Grewia are well-characterized by forming very large stromata with numerous densely arranged conidiophores. The other species on hosts of allied genera are quite distinct: $P$. lueheae U. Braun \& F.O. Freire on Luehea in Brazil (conidiophores up to $250 \times 8 \mu \mathrm{m}$, conidia $25-45 \times 7-11 \mu \mathrm{m}, 1-3-$ septate), P. macutensis (Syd.) Deighton on Corchorus spp. (stroma non, superficial hyphae lacking, 
conidia pale olivaceous), and the African P. triumfettigena (J.M. Yen \& Gilles) Deighton (stromata lacking or poorely developed, conidiophores up to $600 \mu \mathrm{m}$ long, conidia 4-6 $\mu \mathrm{m}$ wide) [Deighton 1976, Braun \& Freire 2006].

\section{Pseudocercospora bradburyae (E. Young) Deighton}

$\equiv$ Cercospora bradburyae E. Young.

Material examined - VENEZUELA, Lara, Sanare, Sabana Redonda Arriba, on living leaves of Centrosema sagittatum (Humb. \& Bonpl. ex Willd.) Brandegee (Fabaceae), June 2009, R. Urtiaga 271 (HAL 2578 F).

Notes - P. bradburyae is known from Venezuela (Crous \& Braun 2003, Iturriaga \& Minter 2006), but $C$. sagittatum is a new host species.

Pseudocercospora clematidis-haenkeanae U. Braun \& Urtiaga, sp. nov.

Fig. 5 MycoBank, MB 803854.

Etymology - epithet derived from the host species, Clematis haenkeana.

Pseudocercosporae clematidicolae similis, sed maculis foliorum pallide bruneolis vel griseoalbidis, stromatibus majoribus, 20-50 $\mu \mathrm{m}$ diam., conidiophoris brevioribus, 5-30 $\mu \mathrm{m}$ et conidiis item brevioribus, 20-60 $\mu \mathrm{m}$ longis et tantum 2-5-septatis.

Leaf spots amphigenous, subcircular to angular-irregular, 1-15 mm diam., pale brownish to greyish white, with a narrow darker and somewhat raised margin. Caespituli amphigenous, rather inconspicuous, greyish white to brownish, indistinctly punctiform, scattered. Mycelium internal and external, superficial hyphae emerging through stomata, branched, septate, 1-2.5 $\mu \mathrm{m}$ wide, subhyaline to very pale olivaceous, thin-walled, smooth. Stromata well-developed, substomatal or immersed, subcircular to somewhat irregular in outline, 20-50 $\mu \mathrm{m}$ diam., somewhat erumpent, medium olivaceous to brown, composed of swollen hyphal cells, 2-6 $\mu \mathrm{m}$ diam. Conidiophores in moderately large, dense fascicles, arising from stromata or conidiophores solitary, arising from superficial hyphae, erect, straight to curved or sinuous, but not distinctly geniculate, unbranched, usually subcylindrical, sometimes clavate (width increasing towards the apex), attenuated towards the tip, conical, 5-30 $\times 1.5-5 \mu \mathrm{m}$, aseptate, occasionally with a single basal septum, subhyaline to pale olivaceous or olivaceous-brown, thin-walled, smooth, apex usually blunt, rounded; conidiophores usually reduced to conidiogenous cells, conidiogenous loci inconspicuous. Conidia solitary, subcylindrical, subclavate or somewhat obclavate-cylindrical, straight to somewhat curved, 20-60 × 4-5 $\mu \mathrm{m}, 2-5$-septate, subhyaline to pale olivaceous, thin-walled, smooth, apex obtuse, base short obconically truncate to rounded, hila 1.5-2 $\mu \mathrm{m}$ diam., neither thickened nor darkened.

Material examined - VENEZUELA, Lara, Rio Claro, La Cuchilla, on leaves of Clematis haenkeana C. Presl (Ranunculaceae), 1 June 1970, R. Urtiaga 1146 (IMI $149403=$ K(M) 180144, holotype).

Notes - Urtiaga (1986) and Iturriaga \& Minter (2006) listed the type collection of this species as Cercospora sp. Among several Pseudocercospora species described on Clematis spp., $P$. clematidis P.N. Singh, Kharwar \& H.S.G. Rao (Singh et al. 1997) has similar, relatively broad conidia and forms superficial hyphae with solitary conidiophores, but the latter species differ from P. clematidis-haenkeanae in having blackish brown leaf spots, much smaller stromata, about $20 \mu \mathrm{m}$ diam., much longer, pluriseptate conidiophores, $15-83 \mu \mathrm{m}$, and much longer conidia, up to $148 \mu \mathrm{m}$, with up to 25 septa. P. clematidis Goh \& W.H. Hsieh (Hsieh \& Goh 1990) is characterized by having short, fasciculate conidiophores giving rise to long, pluriseptate conidia, only $2-3 \mu \mathrm{m}$ wide. P. clematidigena U. Braun \& Crous (Braun \& Crous 2005) [”Cercospora clematidis Boedijn, non Pseudocercospora clematidis Goh \& W.H. Hsieh] is close to P. clematidis, but distinguished by its formation of abundant superficial mycelium with solitary conidiophores. Guo \& Hsieh (1995) assigned such collections to Pseudocercospora clematidis, and Guo \& Liu (in Guo 1989) as well as Liu et al. (1998) to P. squalidula (Peck) Y.L. Guo \& X.J. Liu. However, the latter name is misapplied. The new combination was based on Chinese material, but not on the examination of 


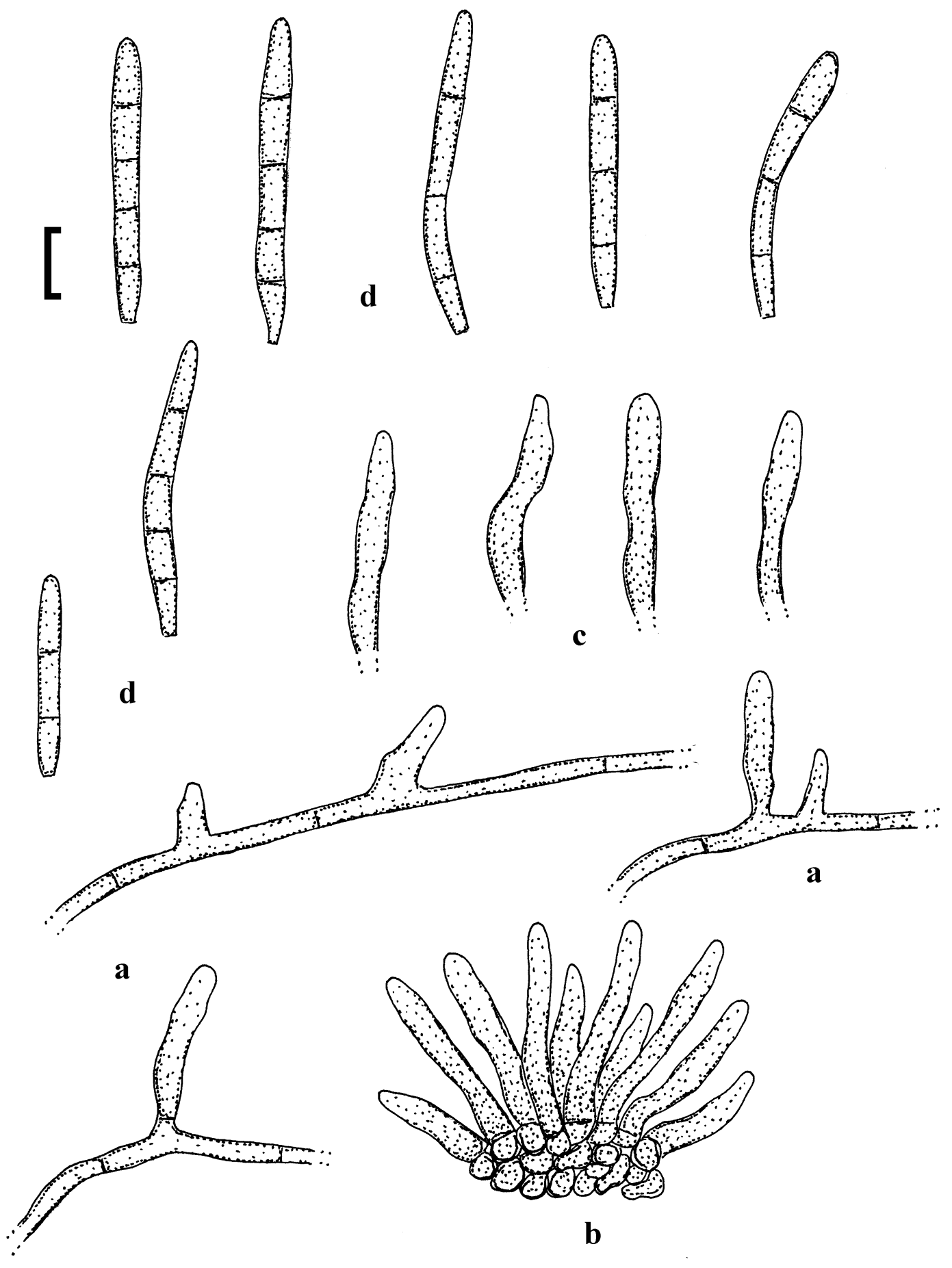

Fig. 5 - Pseudocercospora clematidis-haenkeanae. Based on type material. a Superficial hyphae with solitary conidiophore fascicles. $\mathbf{b}$ Conidiophore fascicles. $\mathbf{c}$ Conidiophores. $\mathbf{d}$ Conidia. - Bar $=$ $10 \mu \mathrm{m}$.

type material. Braun \& Mel'nik (1997) re-examined type material of Cercospora squalidula Peck and found in this species thickened and darkened conidiogenous loci. Later, this species was reallocated to Passalora (Crous \& Braun 2003). In Pseudocercospora ranunculacearum C. Gupta, Abbasi \& Kamal (Gupta et al. 1987) on Clematis sp. in India, long, broad conidiophores (about 40$130 \times 4.5-6 \mu \mathrm{m}$ ) are formed in small fascicles (up to 6). The conidia are obclavate-cylindrical, up to $125 \times 7 \mu \mathrm{m}$, with $4-10$ septa. 
Key to Pseudocercospora species on Clematis

1. Conidiophores fasciculate; superficial mycelium lacking ....................................................... 2

$1 *$ Conidiophores fasciculate as well as solitary, arising from superficial hyphae ........................... 3

2. Conidiophores short, 8-25 $\mu \mathrm{m}, 0-2$-septate; conidia 2-3 $\mu \mathrm{m}$ wide; on Clematis gouriana,

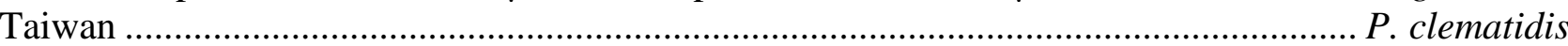

2* Conidiophores longer, up to $130 \mu \mathrm{m}$, up to 4 -septate; conidia up to $7 \mu \mathrm{m}$ wide; on Clematis sp., India

$P$. ranunculacearum

3. Conidia narrow, 2-4 $\mu \mathrm{m}$, often attenuated towards the apex, tips often pointed; on various Clematis spp. in Asia ....................................................................................... P. clematidigena

$3^{*}$ Conidia broader, $3.5-5 \mu \mathrm{m}$, apex usually obtuse, rounded ...................................................... 4

4. Leaf spots blackish brown; stromata small, about $20 \mu \mathrm{m}$ diam.; conidiophores up to about $80 \mu \mathrm{m}$ long and up to 9-septate; conidia up to $150 \mu \mathrm{m}$ long, with up to $25 \mathrm{septa}$; on Clematis sp. in India

P. clematidicola

4* Leaf spots pale brownish to greyish white; stromata larger, 20-50 $\mu \mathrm{m}$ diam.; conidiophores only 5-30 $\mu \mathrm{m}$ long, usually aseptate; conidia 20-60 $\mu \mathrm{m}$ long, 2-5-septate; on Clematis haenkeana, Venezuela

P. clematisis-haenkeanae

Pseudocercospora clitoriae (G.F. Atk.) Deighton

$\equiv$ Cercospora clitoriae G.F. Atk.

Material examined - VENEZUELA, Yaracuy, Cumaripa, on leaves of Clitoria falcata Lam. [= C. rubiginosa Juss. ex Pers.] (Fabaceae), Jul. 1988, R. Urtiaga (IMI) $333653=$ K(M) 180177).

Notes - This species is known from Venezuela on Clitoria ternatea L. (Chupp 1934, 1954, Dennis 1970, Crous \& Braun 2003, Iturriaga \& Minter 2006). The present collection on the new host plant $C$. falcata was recorded as Pseudocercospora sp. in Dennis (1970). Superficial hyphae with solitary conidiophores were described for this species by Deighton (1976), but not in Chupp (1954). In the present collection from Venezuela superficial mycelium is not developed.

Pseudocercospora erythrinicola U. Braun \& Urtiaga, sp. nov.

Fig. 6 MycoBank, MB 803855.

Etymology - epithet referring to the host genus (inhabitant of Erythrina).

Pseudocercosporae diversisporae valde similis, sed maculis foliorum distinctis, stromatibus minoribus, 10-60 $\mu \mathrm{m}$ diam., et conidiophoris latioribus, 2-6.5 $\mu \mathrm{m}$.

Leaf spots amphigenous, almost lacking or only with small vein-limited specks, $0.5-2 \mathrm{~mm}$ diam., occasionally confluent and larger, brownish, greyish brown to dingy grey. Caespituli amphigenous, punctiform, scattered to gregarious, dark brown to blackish. Mycelium internal. Stromata small to well-developed, substomatal to intraepidermal below, intra-epidermal above, 10 $60 \mu \mathrm{m}$ diam., brown, cells $2-6 \mu \mathrm{m}$ diam. Conidiophores in small to moderately large fascicles, loose to dense, arising from stromata, erumpent or emerging through stomata, erect, straight to curved or somewhat sinuous-geniculate, subcylindrical to attenuated towards the tip, 5-25 × 2-6.5 $\mu \mathrm{m}, 0-2(-3)$-septate, pale olivaceous to olivaceous-brown, thin-walled, smooth; conidiogenous cells integrated, terminal or conidiophores aseptate, i.e. reduced to conidiogenous cells, 5-15 $\mu \mathrm{m}$ long, conidiogenous loci inconspicuous or subdenticulate, but always unthickened and not darkened. Conidia solitary, narrowly obclavate-cylindrical, $15-70 \times(1.5-) 2-3(-3.5) \mu \mathrm{m}, 2-7-$ septate, subhyaline to very pale olivaceous, thin-walled, smooth, apex obtuse to mostly subacute, base short to usually longer obconically truncate, $1-1.5 \mu \mathrm{m}$ wide, hila neither thickened nor darkened.

Material examined - VENEZUELA, without locality, on leaves of Erythrina berteroana (Jacq.) Urb. (Fabaceae), 14 Mar. 1969, R. Urtiaga 238 (IMI $139313=$ K(M) 180149, holotype).

Notes - The Asian Pseudocercospora diversispora Goh \& W.H. Hsieh, described from Taiwan on Erythrina corallodendron L., is morphologically close to P. erythrinicola, but differs in having quite distinct leaf spots, larger stromata, up to $90 \mu \mathrm{m}$ diam., and narrower conidiophores, 

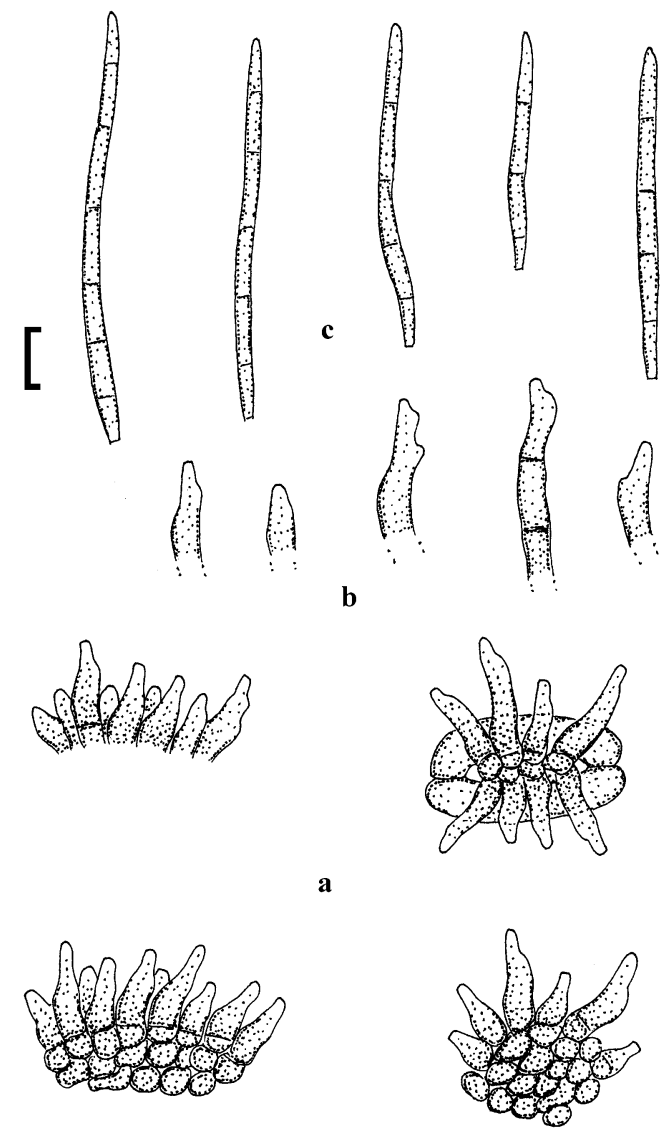

Fig. 6 - Pseudocercospora erythrinicola. Based on type material. a Conidiophore fascicles. b Conidiophores. c Conidia. - Bar $=10 \mu \mathrm{m}$.

1.5-3 $\mu \mathrm{m}$ wide (Hsieh \& Goh 1990). P. erythrinigena J.M. Yen, described from Taiwan on the same host, is also similar but distinct by its quite distinct leaf spots, somewhat narrower subcylindrical-filiform conidia, 1.5-2 $\mu \mathrm{m}$ wide, pale olivaceous brown, with truncate or very short obconically truncate base (Yen 1978, Hsieh \& Goh 1990). P. kaiseri M.D. Mehrotra (Mehrotra 1991), described from India on Erythrina stricta Roxb., is morphologically barely distinguishable from P. erythrinigena and possibly conspecific. P. pulviniformis (Kranz) Deighton on Erythrina senegalensis DC. in Sierra Leone is quite distinct by lacking stromata and its very long conidiophores, 70-220 $\times$ 4-7 $\mu \mathrm{m}$, and much broader conidia, 7-8 $\mu \mathrm{m}$ wide (Kranz 1968). P. pittieri (Syd.) Deighton, widespread on various Erythrina spp., is characterized and distinguished by the formation of superficial hyphae with solitary conidiophores on the lower leaf surface (Chupp 1954).

Pseudocercospora erythroxylicola U. Braun \& Urtiaga, sp. nov.

Fig. 7 MycoBank, MB 8038556. throxylon).

Etymology - epithet derived from the host genus, Erythroxylon (inhabitant of Ery-

Pseudocercosporae erythroxyli similis, sed maculis foliorum majoribus, $1-15 \mathrm{~mm}$ diam., caespitulis saepe hypophyllis, conidiis significanter angustioribus, $2-3.5 \mu \mathrm{m}$ latis, hilis angustioribus, $1-2 \mu \mathrm{m}$ diam.

Leaf spots amphigenous, subcircular to usually angular-irregular, 1-15 $\mathrm{mm}$ diam. medium to medium dark brown, margin indefinite or sometimes surrounded by a narrow ochraceous to pale yellowish brown halo or limited by veins. Caespitili epiphyllous, punctiform scattered to 
aggregated, dark brown to blackish (rarely amphigenous, inconspicuous below, only with a few hyphae or conidiophores emerging through stomata). Mycelium internal; stromata well-developed, immersed, later somewhat erumpent, 30-80 $\mu \mathrm{m}$ diam., medium to dark olivaceous-brown, composed of swollen hyphal cells, 3-7 $\mu \mathrm{m}$ diam. Conidiophores in large fascicles, loose to usually dense, arising from stromata, forming sporodochial conidiomata, erect, straight, subcylindrical to conical, barely geniculate, unbranched, 5-20 × 2-4 $\mu \mathrm{m}$, aseptate, i.e. conidiophores reduced to conidiogenous cells, subhyaline to usually pale olivaceous, thin-walled, smooth or almost so; conidiogenous loci inconspicuous or only visible as truncate tip, 1-2 $\mu \mathrm{m}$ diam., but wall of the loci always unthickened and not darkened. Conidia formed singly, narrowly obclavate to subcylindrical, $(15-) 30-70(-80) \times 2-3.5 \mu \mathrm{m},(1-) 3-7(-8)$-septate, subhyaline to pale olivaceous, thin-walled, smooth to faintly rough-walled, apex obtuse to subacute, base usually short obconically truncate, occasionally truncate, $1-2 \mu \mathrm{m}$ wide, hila unthickened, not darkened.

Material examined - VENEZUELA, Guanare, Papelon, on leaves of Erythroxylum sp. [“hieronimina"] (Erythroxylaceae), Feb. 1989, R. Urtiaga (IMI 333105 = K(M) 180175, holotype).

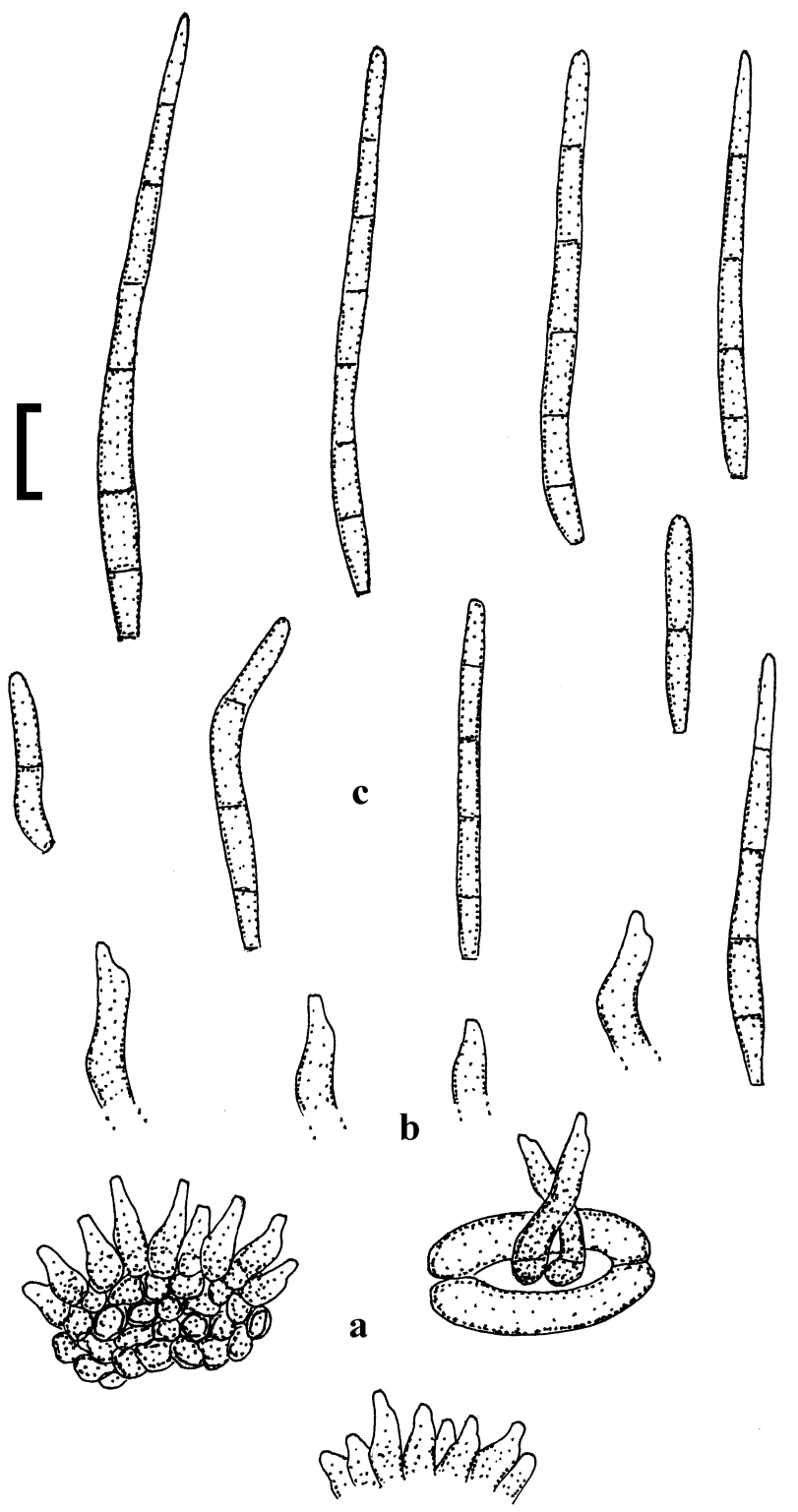

Fig. 7 - Pseudocercospora erythroxylicola. Based on type material. a Conidiophore fascicles. b Conidiophores. c Conidia. - Bar $=10 \mu \mathrm{m}$. 
Notes - Pseudocercospora erythroxyli (Govindu \& Thirum.) U. Braun, Bagyan. \& Jagad. (Vasudeva 1963, Braun et al. 1992), described from India on Erythroxylum monogynum Roxb., is the only comparable species and hitherto the only species of Pseudocercospora on a host of the Erythroxylaceae at all. Sporodochial conidiomata, short conidiophores and conidia with a similar shape are reminiscent of $P$. erythroxylicola, but the leaf spots are smaller, only 1-5 $\mathrm{mm}$ diam., caespituli are hypophyllous, and the conidia are much wider, 3-7 $\mu \mathrm{m}$ and have broader hila, exceeding $2 \mu \mathrm{m}$ (Braun et al. 1992). The type collection of the new species was cited as Pseudocercospora sp. in Iturriaga \& Minter (2006). The species name of the host plant, E. hieronimina, has not been found in pertinent databases and is probably no validly published name.

Pseudocercospora guanarensis U. Braun \& Urtiaga, sp. nov.

Fig. 8 MycoBank, MB 803857.

Etymology - epithet derived from the region of the type locality in Venezuela, Guanare.

Speciebus comparabilibus ad hospites Musioidearum nullis. Pseudocercosporae myriactidis (Asteroideae) valde similis sed conidiis latioribus, 3.5-5.5 $\mu \mathrm{m}$. Differt a P. blumeae-balsamiferae (Asteroideae) conidiophoris angustioribus, 2-5 $\mu \mathrm{m}$, non ramosis, conidiis angustioribus, ad $90 \mu \mathrm{m}$.

Leaf spots amphigenous, 2-8 mm diam., subcircular to angular-irregular, yellowish brown to medium brown on the upper leaf surface, less conspicuous below, margin indefinite or with a darker centre surrounded by a yellowish brown halo. Caespituli amphigenous, inconspicuous. Mycelium internal and external; superficial hyphae emerging through stomata, branched, straight to sinuous, occasionally subgeniculate, septate, 1.5-4 $\mu \mathrm{m}$ wide, subhyaline, pale olivaceous to olivaceous-brown, thin-walled, smooth. Stromata lacking. Conidiophores solitary, arising from superficial hyphae, occasionally with a few conidiophores in loose fascicles, arising from substomatal hyphae, emerging through stomata, conidiophores erect, straight to curved or somewhat sinuous, barely geniculate, unbranched, subcylindrical or somewhat attenuated towards the tip, 5-100 × 2-5 $\mu \mathrm{m}, 0-6$-septate, pale olivaceous to olivaceous-brown, smooth, thin-walled; conidiogenous cells integrated, terminal or conidiophores aseptate, i.e. conidiophores reduced to conidiogenous cells, 5-30 $\mu \mathrm{m}$ long, conidiogenous loci inconspicuous. Conidia solitary, obclavatecylindrical, short conidia sometimes subcylindrical-fusoid, 25-90 × 3.5-5.5 $\mu \mathrm{m}, 2-9$-septate, pale olivaceous to olivaceous-brown, thin-walled, smooth, apex obtuse, occasionally subacute, base short obconically truncate, $1-1.5 \mu \mathrm{m}$ wide, hila neither thickened nor darkened.

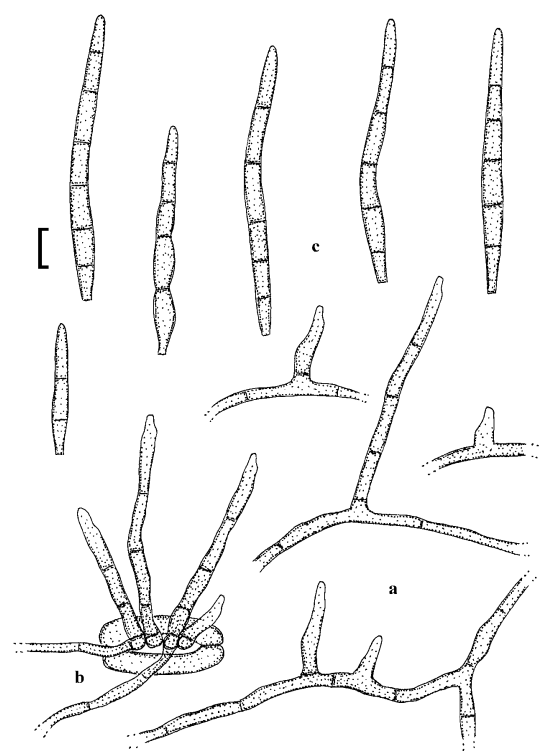

Fig. 8 - Pseudocercospora guanarensis. Based on type material. a Superficial hyphae with solitary conidiophores. b Conidiophores and superficial hyphae emerging through a stoma, arising from superficial hyphae and swollen hyphal cells. c Conidia. - Bar $=10 \mu \mathrm{m}$. 
Material examined - VENEZUELA, Guanare, Papelon, on living leaves of Trixis sp., Feb. 1989, R. Urtiaga (IMI $333097=\mathrm{K}(\mathrm{M})$ 180168, holotype).

Notes - Morphologically comparable species of Pseudocercospora on hosts belonging to the Asteraceae subfam. Mutisioideae are unknown. Among other species there are a few similar taxa, e.g. the Asian P. blumeae-balsamiferae Goh \& W.H. Hsieh on Blumea (Asteroideae, Inuleae), distinguished by broader conidiophores, 4-6 $\mu \mathrm{m}$, and longer conidia, up to $120 \mu \mathrm{m}$, and $P$. myriactidis Goh \& W.H. Hsieh on Myriactis (Asteroideae, Astereae), which has much narrower conidia, 2.5-3.5 $\mu \mathrm{m}$ (Hsieh \& Goh 1990).

Pseudocercospora helicteris U. Braun \& Urtiaga, sp. nov.

Fig. 9 MycoBank, MB 803858.

Pseudocercosporae melochiae et P. melochiigenae similis sed conidiophoris brevi-oribus, 5-25 $\mu \mathrm{m}$, et conidiis item brevioribus, $25-80 \mu \mathrm{m}, 2-9$-septatis.

Leaf spots amphigenous, subcircular to irregular, 2-15 $\mathrm{mm}$ diam., or confluent and larger, on the upper side medium to medium dark brown, later greyish brown, paler on the lower side, margin indefinite, sometimes with a diffuse yellowish to light brownish halo or surrounded by larger diffuse discolorations. Caespituli hypophyllous, rather inconspicuous. Mycelium internal and external; superficial hyphae emerging through stomata, branched, 1-4 $\mu \mathrm{m}$ wide, septate, subhyaline to pale olivaceous-brown, thin-walled, smooth. Stromata small, substomatal to intraepidermal, 10 $30 \mu \mathrm{m}$ diam., brown, cells $2-6 \mu \mathrm{m}$ diam. Conidiophores in small to modereately large fascicles, arising from stromata, through stomata or erumpent, or solitary, arising from superficial hyphae, lateral, rarely terminal, erect, straight to somewhat geniculate-sinuous, unbranched, subcylindrical to somewhat attenuated towards the tip, short, 5-25 $\times 2-4.5 \mu \mathrm{m}, 0-1$-septate, pale olivaceous to olivaceous-brown, thin-walled, smooth; conidiogenous cells integrated, terminal or conidiophores often aseptate, reduced to conidiogenous cells, 5-20 $\mu \mathrm{m}$ long, conidiogenous loci inconspicuous, unthickened and not darkened. Conidia solitary, narrowly obclavate-cylindrical, 25-80 × (2-)2.54(-4.5) $\mu \mathrm{m}, 2-9$-septate, subhyaline to pale olivaceous or brownish, thin-walled, smooth, apex obtuse to subacute, base short obconically truncate, $1-1.5 \mu \mathrm{m}$ wide, hila neither thickened nor darkened.

Material examined - VENEZUELA, Carora, Quediche, Hacienda Sta. Rita, on living leaves of Helicteres guazumifolia Kunth (Malvaceae, Sterculioideae $=$ Sterculiaceae), without date, R. Urtiaga 1832 (IMI $3344202=\mathrm{K}(\mathrm{M})$ 180173, holotype).

Notes - There are several similar Pseudocercospora species on hosts belonging to the former family Sterculiaceae (now Malvaceae subfam. Sterculioideae). P. melochiae (Henn.) Deighton and P. melochiigena H.S.G. Rao, Archana Singh \& Kamal on Melochia spp. are similar but easily distinguishable by having much longer conidiophores, up to $80 \mu \mathrm{m}$, and longer conidia, up to $165 \mu \mathrm{m}$, with up to 15 septa (Chupp 1954, Rao et al. 1998). P. isorae R.K. Verma \& N. Sharma on Helicteres isora L. in India is quite distinct, differing in having fasciculate, longer conidiophores, up to $60 \mu \mathrm{m}$ (superficial hyphae with solitary conidiophores lacking) and much longer and broader conidia, up to $155 \times 5-7.5 \mu \mathrm{m}$ (Verma et al. 2008). P. guazumae (Syd.) Deighton is also similar but forms well-developed epiphyllous caespituli and immersed stromata, 20-50 $\mu \mathrm{m}$ diam. (Chupp 1954).

Pseudocercospora heliotropii U. Braun \& F.O. Freire

Material examined - VENEZUELA, Guanare, Ospino, on leaves of Heliotropium procumbens Mill. [= H. inundatum Sw.] (Boragiaceae), Feb. 1989, R. Urtiaga (IMI $333652=$ $\mathrm{K}(\mathrm{M})$ 180172).

Notes - This species, described from Brazil on Heliotropium sp. (Braun \& Freire 2002), is new to Venezuela. 

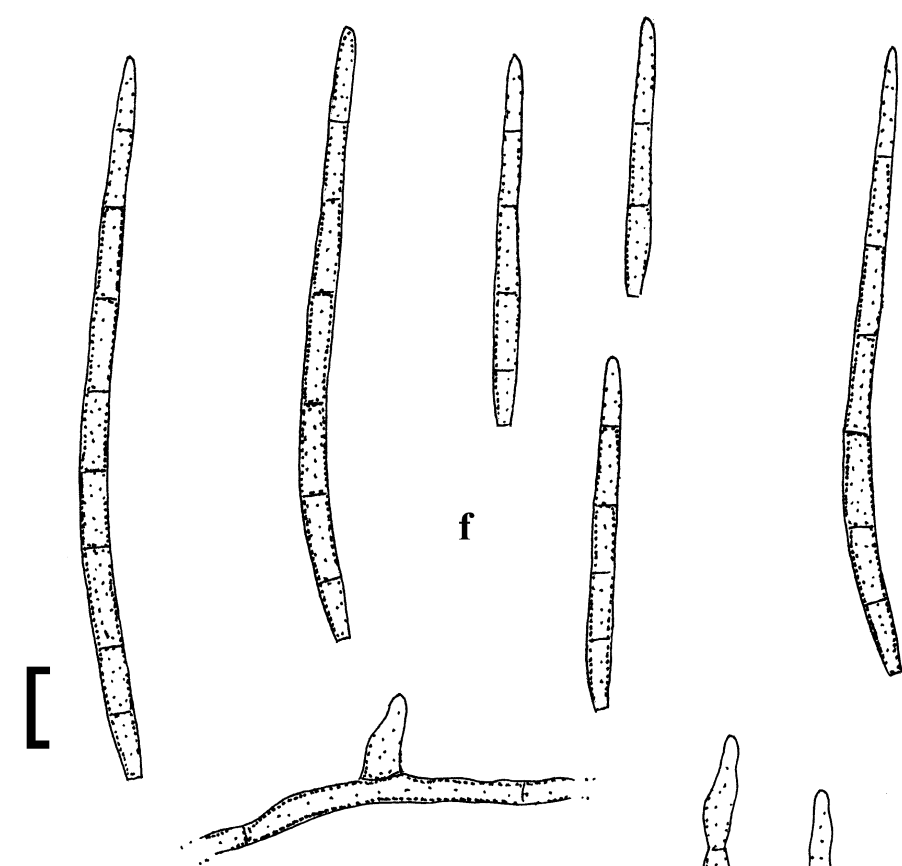

b
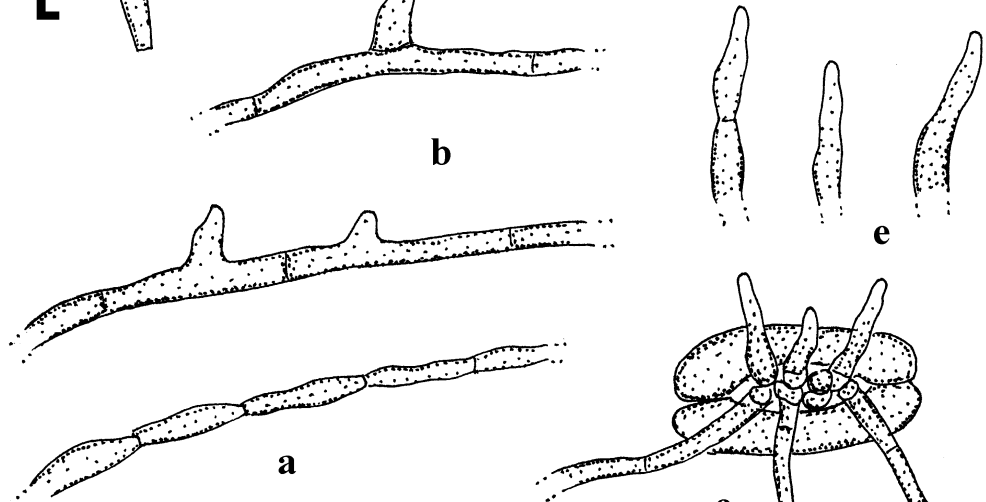

a

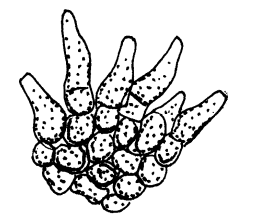

d
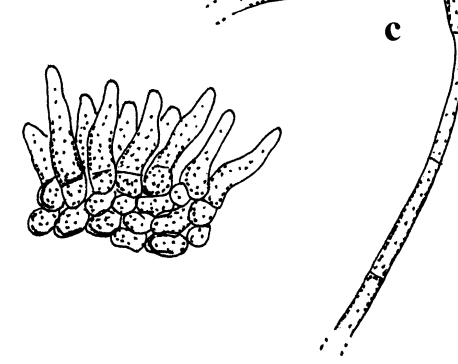

Fig. 9 - Pseudocercospora helicteris. Based on type material. a Superficial hypha. b Solitary conidiophores arising from superficial hyphae and swollen hyphal cells. c Conidiophores and superficial hyphae emerging through a stoma. d Conidiophore fascicles. e Conidiophores. f Conidia. - Bar $=10 \mu \mathrm{m}$.

\section{Pseudocercospora jahnii (Syd.) U. Braun \& Crous}

Material examined - VENEZUELA, Carabobo, Chirgua zone, Monte Sacro farm, on leaves of Godmania aesculifolia (Kunth) Standl. [ $\equiv$ Tabebuia aesculifolia (Kunth) Hemsl., = Godmania macrocarpa (Benth.) Hemsl.], Nov. 1997, R. Urtiaga (IMI $381675=$ K(M) 180165); Lara, la Pastora, on leaves of Tabebuia chrysea S.F. Blake, June 1992, R. Urtiaga (IMI $357424=$ K(M) 180167).

Notes - The well-developed collection on Godmania aesculifolia agrees well with P. jahnii. G. aesculifolia is a new host for this species. The specimen on Tabebuia chrysea, which would also be a new host for $P$. jahnii, is immature, poorly developed and contains above all stromata without any conidiophores or only with initials. It seems to belong to $P$. jahnii, but can only be assigned to this species tentatively. The latter collection is cited in Iturriaga \& Minter (2006) as Pseudocercospora sp. 
Pseudocercospora piperis (Pat.) Deighton

$\equiv$ Cercospora piperis Pat.

Material examined - VENEZUELA, Lara, Rio Claro, La Cuchilla, on leaves of Piper aduncum L. (Piperaceae), Mar. 2006, R. Urtiaga 4 (HAL 2157 F).

Notes - This species is known from Venezuela, also on this host (Chupp 1954, Crous \& Braun 2003, Urtiaga 1986, Iturriaga \& Minter 2006).

Pseudocercospora ranjita (S. Chowdhury) Deighton var. amphigena U. Braun, nom. nov. MycoBank, MB 803860.

Bas.: Cercospora gmelinae J.M. Yen \& Gilles, Bull. Trimestriel Soc. Mycol. France 91: 99, 1975.

三Pseudocercospora gmelinae (J.M. Yen \& Gilles) J.M. Yen.

Material examined - VENEZUELA, Barquisimeto, on leaves of Gmelina arborea Roxb. (Lamiaceae), 23 Sep. 1985, R. Urtiaga (IMI 298014 = K(M) 180174).

Notes - Urtiaga (1986) listed Pseudocercospora gmelinae as well as P. ranjita on Gmelina arborea from Venezuela (see also Crous \& Braun 2003, Iturriaga \& Minter 2006). Yen (1975) introduced $C$. gmelinae, compared it with $C$. ranjita and differentiated the two species on the base of amphigenous and hypophyllous fructification, respectively. Furthermore, $P$. ranjita was described to have small hypophyllous stromata or stromata are lacking, whereas epiphyllous stromata in P. gmelinae are larger, 28-60 $\mu \mathrm{m}$ (Yen 1975, Guo \& Hsieh 1995, Guo et al. 1998). All other characters, above all conidiophores and conidia, are indistinguishable between the two taxa. Pseudocercospora species with differences between epiphyllous and hypophyllous caespituli are common. Collections with amphigenous caespituli and larger stromata and conidiophore fascicles are barely more than a variety of $P$. ranjita. As $P$. ranjita (var. ranjita) also occurs on Gmelina arborea, "var. gmelinae" is inappropriate as variety name. Therefore, the new name var. amphigena is proposed. The collection from Venezuela, belonging to var. gmelinae, is characterized as follows: Stromata on the upper side immersed, substomatal below, 10-50 $\mu \mathrm{m}$ diam.; conidiophores fasciculate, arising from stromata or solitary, arising from superficial hyphae, 5-50 $\times 3-6 \mu \mathrm{m}, 0-3$-septate; conidia obclavate-subcylindrical, 20-100 $\times 3-6.5 \mu \mathrm{m}, 2-11$-septate.

Pseudocercospora simirae U. Braun, sp. nov.

Fig. 10

MycoBank, MB 803861

Etymology - referring to the host genus, Simira.

Pseudocercosporae calycophylli similis sed conidiis brevioribus, 10-55 $\mu \mathrm{m}$, tantum 1-4septatis.

Leaf spots amphigenous, subcircular to angular-irregular, 2-20 mm diam. or confluent and larger, finally covering large leaf segments or even leaves, brown, later turning greyish brown to greyish white, margin indefinite or darker. Caespituli amphigenous, conspicuous on the upper side, punctiform, scattered, dark brown to blackish, less conspicuous on the lower side. Mycelium internal and external; superficial hyphae above all hypophyllous, branched, 1-3 $\mu \mathrm{m}$ wide, subhyaline to pale olivaceous, smooth. Stromata 10-60 $\mu \mathrm{m}$ diam., occasionally confluent and larger, immersed on the upper side, substomatal below, olivaceous-brown, cells $2-5 \mu \mathrm{m}$ diam. Conidiophores in small to usually moderately large fascicles, loose to dense, arising from stromata, through stomata or erumpent, or solitary, arising from superficial hyphae, erect, straight, subcylindrical to curved or somewhat geniculate-sinuous, usually not branched, 5-50 $\times 2-4.5 \mu \mathrm{m}, 0$ 1(-2)-septate, subhyaline to pale olivaceous, thin-walled, smooth; conidiogenous cells integrated, terminal or conidiophores reduced to conidiogenous cells, 5-25 $\mu \mathrm{m}$ long, conidiogenous loci inconspicuous, occasionally subdenticulate, but always unthickened and not darkened. Conidia solitary, obclavate-cylindrical, occasionally fusiform, 10-55 × 2-3.5 $\mu \mathrm{m}, 1$-4-septate, subhyaline to pale olivaceous, wall thin, smooth, apex obtuse to subacute, base obconically truncate, hila 1-1.5 $\mu \mathrm{m}$ diam., neither thickened nor darkened. 


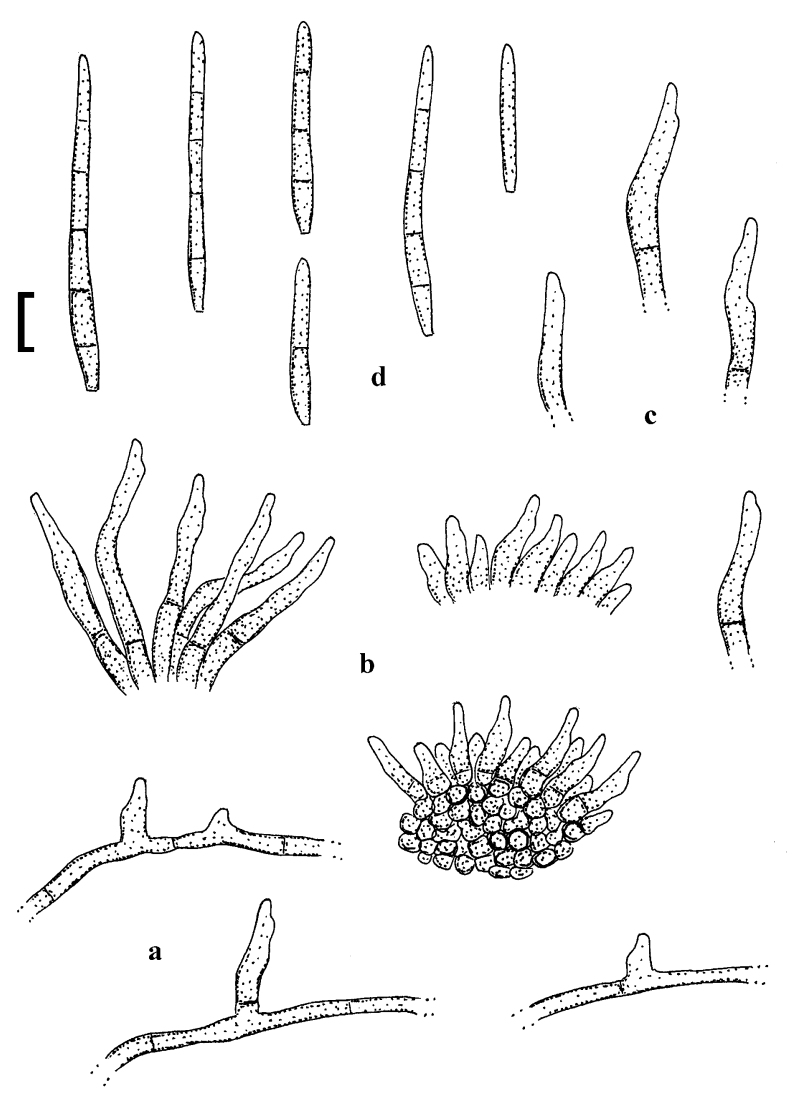

Fig. 10 - Pseudocercospora simirae. Based on type material. a Solitary conidiophores arising from superficial hyphae. b Conidiophore fascicles. c Conidiophores. d Conidia. - Bar $=10 \mu \mathrm{m}$.

Material examined - VENEZUELA, Lara, Barquisimeto, zoological garden, on leaves of Simira erythroxylon (Willd.) Bremek. (Rubiaceae, Ixorioideae, Condamineeae), May 1989, R. Urtiaga (IMI $333092=\mathrm{K}(\mathrm{M})$ 180171, holotype).

Notes - Pseudocercospora simirae is characterized by having solitary conidiophores arising from superficial hyphae as well as fasciculate conidiophores arising from well-devloped stromata. The conidiophores are relatively short, only $0-1(-2)$-septate and pale, and the obclavate-cylindrical conidia are also relatively short and narrow, only with 1-4 septa. Among the numerous Pseudocercospora species on rubiaceous hosts there are only few morphologically similar species on hosts of allied genera within the Ixorioideae. P. calycophylli U. Braun \& Urtiaga, described from Venezuela on Calycophyllum candidissimum (Vahl) DC. (Ixorioideae, Condamineeae [Cichonoideae, Calycophylleae]) is morphologically very similar but has much longer conidia, up to $120 \mu \mathrm{m}$, with up to 10 septa (Braun \& Urtiaga 2013). P. palicoureina (Petr. \& Cif.) U. Braun on Palicourea spp. (Rubioideae, Psychotrieae) is also rather similar, but differs in having small fascicles of conidiophores arising from smaller stromata and broader conidia, 3-4.5 $\mu \mathrm{m}$ (Chupp 1954, Braun 2001b, Braun \& Urtiaga 2012). The South African P. psychotriicola (Chupp \& Doidge) Crous \& U. Braun on Psychotria (also Rubioideae, Psychotrieae) is an additional morphologically close species, but the conidia are much longer, up to $120 \mu \mathrm{m}$, and pluriseptate (Chupp 1954, Crous \& Braun 1994). P. genipicola U. Braun \& F.O. Freire on Genipa americana L. (Gardenieae) in Brazil and Venezuela (Braun \& Freire 2004, Braun \& Urtiaga 2013) is distinguished from $P$. simirae by its very large stromata, up to $100 \mu \mathrm{m}$ diam., and somewhat wider conidia, 2.5-4.5 $\mu \mathrm{m}$, and P. pavettae-indicae (Govindu \& Thirum.) J.M. Yen, A.K. Kar \& B.K. Das on Pavetta indica L. (Pavetteae) in India has much smaller leaf spots, 1-4 mm diam., and longer and wider conidia, up to $80 \times 3-5(-6) \mu \mathrm{m}$ (Yen et al. 1982). 
Pseudocercospora tamoneae (Chupp) U. Braun \& R.F. Castañeda

Material examined - VENEZUELA, Lara; Sanare, Sabana Redonda Arriba, on living leaves of Miconia theaezans (Bonpl.) Cogn. (Melastomataceae), June 2009, R. Urtiaga 256 (HAL 2581 F).

Notes - New to Venezuela and on a new hosts species.

Pseudocercospora trematigena U. Braun \& F.O. Freire

Material examined - VENEZUELA, Lara, Duaca zone, on leaves of Trema micrantha (L.) Blume (Cannabaceae), Nov. 1993, R. Urtiaga (IMI 361862 = K(M) 180169); 1.c., Apr. 2009, R. Urtiaga 203 (HAL 2550 F).

Notes - This species, described from Brazil on Trema micrantha (Braun \& Freire 2006), is new to Venezuela. The present collection is listed in Iturria \& Minter (2006) under Pseudocercospora sp. The leaf spots in the collections from Venezuela are up to $10 \mathrm{~mm}$ diam., conidiophores are up to $40 \mu \mathrm{m}$ long and the conidia are up to $120 \times 3-4.5 \mu \mathrm{m}$, with up to 11 septa. Otherwise it coincides with the type collection from Brazil.

Zasmidium asclepiadis U. Braun \& Urtiaga (Braun \& Urtiaga 2012: 324)

Notes - On the label of the type collection (IMI $146225=\mathrm{K}(\mathrm{M})$ 173065), the exact locality in Venezuela was not given (published as "without locality"). However, the type locality is: Venezuela, Lara, Anzoategui.

Zasmidium cassiae-grandis U. Braun \& Urtiaga, sp. nov.

Fig. 11 MycoBank, MB 803862

Etymology - derived from the host species, Cassia grandis.

Differt ab omnibus speciebus Zasmidii ad species Cassiae et Sennae conidiophoris brevioribus, 5-50 × 2.5-7 $\mu \mathrm{m}$, et conidiis latioribus, 15-90 × 3-7 $\mu \mathrm{m}$, valde verrucosis, crassitunicatis.

Leaf spots lacking or only causing slight discolorations on the lower leaf surface. Colonies hypophyllous, rarely epiphyllous, forming sooty patches, 1-10 mm diam., loose to rather dense, later confluent and larger, covering large leaf segments. Mycelium internal and external; superficial hyphae branched, septate, 1.5-5 $\mu \mathrm{m}$ wide, pale olivaceous to medium olivaceous-brown, fertile hyphae around conidiophores often wider and darker, up to $6.5 \mu \mathrm{m}$, wall thin to somewhat thickened, verruculose to verrucose. Stromata lacking. Conidiophores solitary, arising from superficial hyphae, lateral, occasionally terminal, erect, straight, distinctly geniculate-sinuous, often with constrictions and swellings, unbranched, subcylindrical or attenuated towards the tip, 5-50 $\times$ 2.5-7 $\mu \mathrm{m}$, rarely longer, 0-3-septate, medium to dark brown or olivaceous-brown, wall somewhat thickened, up to $1 \mu \mathrm{m}$, distinctly verruculose to verrucose; conidiogenous cells integrated, terminal or conidiophores aseptate, i.e conidiophores reduced to conidiogenous cells, 2-20 $\mu \mathrm{m}$ long, conidiogenous loci conspicuous, thickened and darkened, 1.5-2.5 $\mu \mathrm{m}$ diam. Conidia solitary and in simple or branched chains, cylindrical or subcylindrical, 15-90 × 3-7 $\mu \mathrm{m}, 0-10$-septate, pale olivaceous to medium dark olivaceous-brown, wall thin to somewhat thickened, up to $1 \mu \mathrm{m}$, coarsely verruculose-verrucose, cell lumina sometimes reduced, ends rounded to truncate or very short obconically truncate, hila 1.5-2.5 $\mu \mathrm{m}$ diam. somewhat thickened and darkened.

Material examined - CUBA, Bayamo, on living leaves of Cassia grandis L. f. (Fabaceae), 28 Jan. 1967, R. Urtiaga (IMI $125069=\mathrm{K}(\mathrm{M})$ 180139, holotype).

Notes - Several Zasmidium species have been described from India on hosts of the allied genera Cassia and Senna. All of them are easily distinguishable. Z. cassiae-fistulae (U. Braun \& Kamal) Kamal \& U. Braun [三 Stenella cassiae Abbasi \& D.N. Shukla, nom. inval., = S. cassiae Kamal, R.P. Singh \& P. Kumar p.p. (nom. confus.)] (Braun et al. 2003, Kamal 2010) differs from Z. cassiae-grandis in having longer and narrower conidiophores, up to $150 \times 2-4.5 \mu \mathrm{m}$, and somewhat narrower, verruculose conidia consistently formed singly. The conidia of $Z$. satpurensis N. Sharma, K.K. Soni \& R.K. Verma (Sharma et al. 2006) are also formed singly. In all other Zasmidium species on Cassia and Senna, the conidia are formed in chains. In Z. cassiicola (S. 

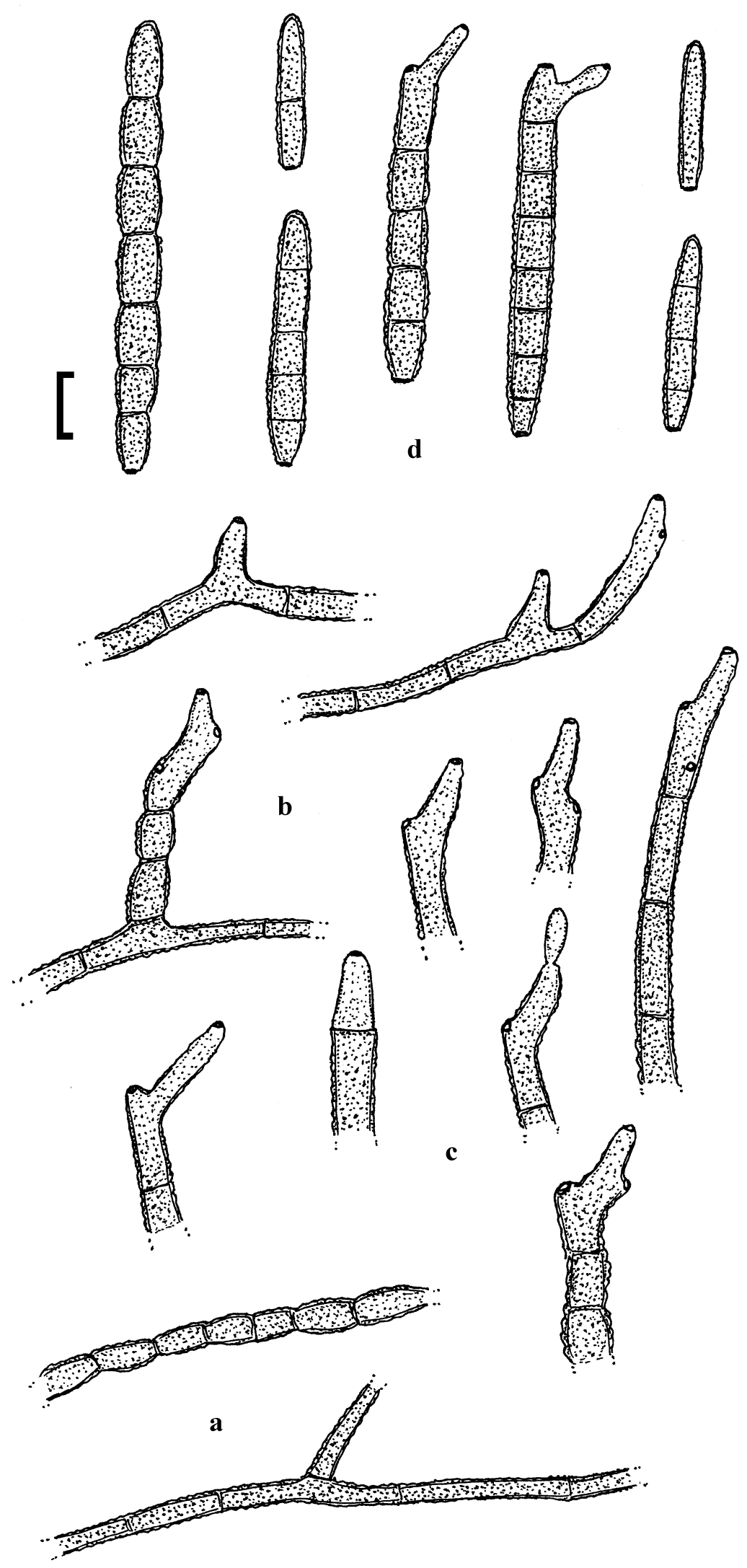

Fig. 11 - Zasmidium cassiae-grandis. Based on type material. a Superficial hyphae. b Solitary conidiophores arising from superficial hyphae. $\mathbf{c}$ Conidiophores. $\mathbf{d}$ Conidia. - Bar $=10 \mu \mathrm{m}$. 
Mishra, A.K. Srivast. \& Kamal) Kamal (= Stenella cassiigena S. Chaudhary \& R.K. Chaudhary), the conidiophores are narrower, 1.5-4 $\mu \mathrm{m}$, and the conidia are shorter and narrower, 20-50 $\times 1.5-$ $4.5 \mu \mathrm{m}$ (Mishra et al. 1999, Kamal 2010). Z. cassiae-occidentalis Kamal (三 Stenella cassiigena Arv.. Kumar, Anju Kumar \& Kharwar) is characterized by the formation of small substomatal stromata and solitary as well as fasciculate conidiophore, long, up to $140 \mu \mathrm{m}$, and subhyaline to pale olivaceous, 1-4-septate, verruculose conidia (Kumar et al. 2006, Kamal 2010). Z. cassiaetorae (S.K. Singh, K. Bhalla \& D.J. Bhat) Kamal is very close to Z. cassiae-occidentalis and possibly conspecific, but differs in having much shorter conidiophores (Singh et al. 2001, Kamal 2010). Therefore, we prefer to maintain this species tentatively.

Stenella chandleri (Hansf.) Suj. Singh \& Kamal was previously applied to Indian collections of Zasmidium on Cassia fistula based on the misapplication of this name by Singh \& Kamal (1979), but the collections concerned belong to Z. cassiae-fustulae (= Stenella cassiae Abbasi \& D.N. Shukla). The true Stenella chandleri is an African species on Pseudospondias microcarpa Engl., Anacardiaceae (see Crous \& Braun 2003).

Key to Zasmidium species on Cassia and Senna spp.

1. Conidiophores formed singly, arising from superficial hyphae, and in small fascicles from small substomatal stromata .... 2

$1 *$ Conidiophores only solitary, arising from superficial hyphae, stromata and fascicles lacking ..... 4

2. Conidia formed singly, hila barely thickened and darkened; on Cassia fistula, India.....

Z. satpurensis

$2 *$ Conidia catenate; on other hosts 3

3. Conidiophores about 50-140 $\mu \mathrm{m}$ long; on Senna occidentalis, India............. cassiae-occidentalis

3* Conidiophores shorter, about 15-75 $\mu \mathrm{m}$; on Senna tora, India Z. cassiae-torae

4. Conidia consistently solitary, 15-100 × 2-6 $\mu \mathrm{m}$; on Cassia fistula, India............ Z. cassiae-fistulae

4* Conidia in chains

5. Conidiophores relatively short, 5-50 × 2.5-7 $\mu \mathrm{m}$, coarsely rough-walled; conidia 15-90 × 3-7 $\mu \mathrm{m}$, pale olivaceous to dark olivaceous-brown, coarsely verrucose; on Cassia grandis, Cuba......

Z. cassiae-grandis

$5^{*}$ Conidiophores longer, 30-90 $\mu \mathrm{m}$, narrower, 1.5-4 $\mu \mathrm{m}$; conidia shorter and narrower, 20-50 $\times$ 1.5-4.4 $\mu \mathrm{m}$, fainly verruculose, subhyaline to olivaceous-brown; on Cassia fistula, India.

Z. cassiicola

Zasmidium citri-grisea (F.E. Fisher) Crous

$\equiv$ Cercospora citri-grisea F.E. Fisher.

$\equiv$ Stenella citri-grisea (F.E. Fisher) Sivan.

= Mycosphaerella citri Whiteside.

Material examined - VENEZUELA, without locality, on leaves of Citrus ×aurantium var. sinensis L. [ $\equiv$ C. ×sinensis (L.) Osbeck] (Rutaceae), 1972, R. Urtiaga (IMI $166609=\mathrm{K}(\mathrm{M})$ 180143).

Notes - New to Venezuela, neither listed in Crous \& Braun (2003) nor in Iturriaga \& Minter (2006).

\section{Acknowledgements}

We are much obliged to the mycology curator of the Kew Herbarium (K) for the possibility to examine collections previously deposited by R. Urtiaga at IMI.

\section{References}

Arnold GRW. 1986 - Lista de hongos fitopatõgenos de Cuba. Editorial Científico-Técnica, Ciudad de la Habana. 
Bagyanarayana G, Braun U, Jagadeeswar P. 1995 - Notes on Indian Cercosporae and allied genera (IV). Cryptogamic Botany 5, 363-366.

Bhalla K, Sarbhoy AK, Kulshrestha M, Kushwaha KPS. 2001 - New species of Phaeoramularia, Pseudocercospora and Stenella from Western Ghats of India. Microbiological Research 156: 107-112.

Braun U. 1998 - A monograph of Cerco-sporella, Ramularia and allied genera (phytopathogenic hyphomycetes). Vol. 2. IHW-Verlag Eching.

Braun U. 2000 - Miscellaneous notes on some micromycetes. Schlechtendalia 5, 31-56.

Braun U. 2001a - Revision of Cercospora species described by K.B. Boedijn. Nova Hedwigia 73, 419-436.

Braun U. 2001b - Taxonomic notes on some species of the Cercospora complex (VII). Fungal Diversity 8, 41-71.

Braun U, Castañeda RF. 1991 - Cercospora and allied genera of Cuba (II). Cryptogamic Botany 2/3, 289-297.

Braun U, Crous PW. 2005 - Additions and corrections to names published in Cercospora and Passalora. Mycotaxon 92, 395-416.

Braun U, Freire FCO. 2002 - Some cercsporoid hyphomycetes from Brazil - II. Cryptogamie, Mycologie 23, 295-328.

Braun U, Freire FCO. 2004 - Some cercosporoid hyphomycetes from Brazil - III. Cryptogamie, Mycologie 25, 221-244.

Braun U, Freire FCO. 2006 - Some cercosporoid hyphomycetes from Brazil - IV. Crypto-gamie Mycologie 27, 231-248.

Braun U, Mel'nik VA. 1997 - Cercosporoid fungi from Russia and adjacent countries. Trudy Botanicheskogo Instituta Imeni V.L. Komarova, Rossijskaya Akademiya Nauk St. Petersburg, 20, 1-130.

Braun U, Urtiaga R. 2008 - New species and new records of cercosporoid hyphomycetes from Venezuela. Feddes Repertorum 119, 484-506.

Braun U, Urtiaga R. 2012 - New species and new records of cercosporoid hyphomycetes from Cuba and Venezuela (Part 1). Mycosphere 3, 301-329.

Braun U, Urtiaga R. 2013 - New species and new records of cercosporoid hyphomycetes from Cuba and Venezuela (Part 2). Mycosphere 4, 165-205.

Braun U, Bagyanarayana G, Jagadeeswar P. 1992 - Notes on Indian Cercosporae and allied genera (II). International Journal of Mycology and Lichenology 4, 361-374.

Braun U, Crous PW, Kamal. 2003 - New species of Pseudocercospora, Pseudocercosporella, Ramularia and Stenella (cercosporoid hyphomycetes). Mycological Progress 2, 197-208.

Braun U, Freire FCO, Urtiaga R. 2010 - New species and new records of cercosporoid hyphomycetes from Brazil, New Zealand and Venezuela. Polish Botanical Journal 55, 281291.

Castañeda RF, Braun U. 1989 - Cercospora and allied genera of Cuba (I). Cryptogamic Botany 1: 42-55.

Chupp C. 1934 - Cercosporae. In: Mycological explorations of Venezuela (eds Chardon LE, Toro RA). Monographs of the University of Puerto Rico, Series B, 2, 241-255.

Chupp C. 1954 - A monograph of the fungus genus Cercospora. Ithaca.

Crous PW, Braun U. 1994 - Cercospora species and similar fungi occurring in South Africa. Sydowia 46, 204-224.

Crous PW, Braun U. 2003 - Mycosphaerella and its anamorphs: 1. Names published in Cercospora and Passalora. CBS Biodiversity Series 1: 1-569.

Crous PW, Braun U, Alfenas AC. 1999 - Cercosporoid fungi from Brazil. 3. Mycotaxon 72: 171193.

Deighton FC. 1976 - Studies on Cercospora and allied genera. VI. Pseudocercospora Speg., Pantospora Cif. and Cercoseptoria Petr. Mycological Papers 140, 1-168. 
Deighton FC. 1979 - Studies on Cercospora and allied genera. VII. New species and redispositions. Mycological Papers 144, 1-56.

Dennis RWG. 1970 - Fungi of Venezuela and adjacent countries. Kew Bulletin Additional Series 3, 1-531.

Ellis MB. 1976 - More Dematiaceous Hyphomycetes. CAB, Kew.

Firdousi SA, Rai AN, Vyas KM. 1991 - New Cercospora species on monocotyledons from India. Indian Phytopathology 44, 225-227.

García CE, Pons N, de Rojas CB. 1996 - Cercospora y hongos similares sobre especies de Ipomoea. Fitopatología Venezolana 9, 22-36.

Guo YL. 1989 - Foliicolous hyphomycetes of Shennongjia, Hubei Province. Fungi and Lichens of Shennongjia, 341-385.

Guo YL, Hsieh WH. 1995 - The genus Pseudocercospora in China. Mycosystema Monographicum Series 2, 1-388.

Guo YL, Liu XJ, Hsieh WH. 1998 - Flora Fungorum Sinicorum. Vol. 9, Pseudocercospora. Science Press, Beijing.

Guo YL, Liu XJ, Hsieh WH. 2005 - Flora Fungorum Sinicorum. Vol. 24, Cercospora. Science Press, Beijing.

Gupta C, Abbasi P, Kamal. 1987 - Persperctives in Mycological Reaseach - 1 (Prof. G.P. Agarwal Festschrift Volume), 10-17.

Hsieh WH, Goh TK. 1990 - Cercospora and Similar Fungi from Taiwan. Taipei.

Iturriaga T, Minter DW. 2006 - Fungi of Venezuela. www.cybertruffle.org.uk [website, version $1.00]$.

Kamal. 2010 - Cercosporoid Fungi of India. Bishen Singh Mahenda Pal Singh, Dehra Dun.

Kirk PM. 1983 - New or interesting microfungi X. Hyphomycetes on Laurus nobilis leaf litter. Mycotaxon 18, 259-298.

Kranz J. 1968 [“1966“] - Neue Cercospora Arten aus Westafrika. Sydowia 20, 73-83.

Kumar A, Kumar A, Kharwar RN. 2006 - Two new phytopathogenic hyphomycetes from Varanasi, India. Indian Phytopathology 59, 85-90.

Liu XJ, Guo YL, Hsieh WH. 1998 - Flora Fungorum Sinicorum. Vol. 9, Pseudocercospora. Science Press, Beijing.

Meeboon J, Hidayat I, To-anun C. 2007 - Cercosporoid fungi from Thailand. 3. Two new species of Passalora and six new records of Cercospora species. Mycotaxon 102, 139-145.

Meenu, Bhalla K, Singh SK. 1996 - New phytopathogenic hyphomycetes from the Terai belt of Uttar Pradesh, India. Mycological Research 100, 610-612.

Mercado Sierra Á, Holubová-Jechová V, Mena-Portales J. 1997 - Hifomicetes Dematiáceos de Cuba. Enteroblásticos. Museo Regional di Scienze Naturali [Vol. 23]. Turino.

Mehrotra MD. 1991 - Pseudocercospora kaiseri sp. nov. causing a necrotic leaf spot of Erythrina. European Journal of Forest Pathology 21, 124-126.

Mishra S, Srivastava AK, Kamal. 1999 - Further additions to Stenella from India and Nepal. Mycological Research 103, 268-270.

Muntañola M. 1960 - Algunos hyphomycetes criticos. Lilloa 30, 165-232.

Nag Rai TR, Thirumalachar MJ, Govindu HC. 1970 - Notes on some Indian Cercosporae. XII. Sydowia 24, 297-301.

Narayan S, Kharwar RN, Bhartiya HD. 1997 - Some new Cercospora sensu stricto causing leaf spots on vegetable plants from Indian subcontinent. Kavaka 25, 87-92.

Narayan S, Kharwar RN, Singh RK. 2001 - Some additions to Cercospora from Indian subcontinent. Kavaka 28/29, 59-72.

Pons N. 1984 - Hyphomycetes de Venezuela. I. Mycovellosiella boldoae Pons sp. nov., M. brachycarpa (H. Syd.) Deighton y Phaeoramularia rauwolfiae Deighton. Ernstia 23, 1726.

Pons N. 1988 - Ocurrencia de Cercospora aurantiae sobre Citrus spp. en Venezuela. Fitopatología Venezolana 1, 8-13. 
Pons N. 1993 - Phaeoramularia ciccaronei sp. nov., hongo causante de la mancha en cadena en Sorghum spp. Fitopatología Venezolana 6, 2-7.

Pons N. 2004 - Especies de Pseudocercospora en colecciones micológicas de Carmen Emilia Benítez. Ernstia 14, 27-36.

Pons N. 2007 - Cercospora apii s. lat. en Venezuela. Revista de la Facultad de Agronomía de la Universidad del Zulia 24, 399-414.

Rai B, Kamal. 1985 - New hyphomycetes from India. Transactions of the British Myco-logical Society 85, 566-570.

Rao HSG, Moses AS, Narayan S. 1996 - Some new species of Pseudocercospora associated with leaf spots in forest flora of North-eastern Uttar Pradesh. Indian Phytopathology 49: 136141.

Rao HSG, Narayan S, Singh A. 1998 - New species of Pseudocercospora from India. Mycological Research 102, 157-162.

Sharma N, Soni KK, Verma RK. 2006 - Some new hyphomycetes from forests of Satpura. Indian Journal of Tropical Biodiversity 14(1): 34-40.

Singh PN, Kharwar RN, Rao HSG. 1997 - Additions to hyphomycete genus Pseudo-cercospora. Indian Phytopathology 50: 7-15.

Singh SK, Bhalla K, Bhat DJ. 2001 - Four new foliicolous hyphomycetes from Vindhya Hills, India. Indian Journal of Mycology and Plant Pathology 31, 277-286.

Urtiaga R. 1986 - Indice de Enfermedades en Plantas de Venezuela y Cuba.

Vasudeva RS. 1963 - Indian Cercosporae. Indian Council of Agricultural Research, New Delhi.

Verma RK, Sharma N, Soni KK, Jamaluddin. 2008 - Forest Fungi of Central India. International Book Distributing Co., Lucknow.

Vilaró Carmina M, Mena Portales J, Minter DW. 2006 - Fungi of Cuba. www.cybertruffle.org.uk/venefung [website, version 1.00].

Yen JM. 1975 - Les Cercospora de Cote d'Ivoire. - II. Bulletin Trimestiel de la Société Mycologique de France 91: 89-103.

Yen JM. 1978 - Étude sur les champignons parasites du Sud-Est asiatique. 33.: Les Cercospora de Formose, V. Les Pseudocercospora. Bulletin Trimestiel de la Société Mycologique de France 94: 385-389.

Yen JM, Sun SK. 1983 - Studies on parasitic fungi from South East Asia, 48: Cercospora and allied genera of Taiwan, VIII. Cryptogamie Mycology 4, 189-198.

Yen JM, Kar AK, Das BK. 1982 - Studies on Hyphomycetes from West Bengal, India, II. Cercospora and allied genera of West Bengal, 2. Mycotaxon 16, 58-79. 